\title{
A szociális gazdaságtól a szolidáris gazdaságig - a helyi gazdaságfejlesztési modell átalakulása
}

\section{From social economy to solidarity economy - Model change in the development of the local economy}

\author{
CSOBA JUDIT
}

CSOBA Judit: egyetemi tanár, Debreceni Egyetem, Bölcsészettudományi Kar, Politikatudományi és Szociológiai Intézet, Szociológiai és Szociálpolitikai Tanszék; 4032 Debrecen, Egyetem tér 1.; csoba.judit@arts.unideb.hu; https://orcid.org/0000-0001-5285-521X

KULCSSZAVAK: szociális gazdaság; szolidáris gazdaság; harmadik szektor; szociális szövetkezet; társadalmi vállalkozás

ABSZTRAKT: Az ezredforduló környékén a szociális gazdaságot sokan olyan útkereszteződésnek tekintették, ahol a fejlesztéspolitika és a foglalkoztatáspolitika, a piaci, az állami és civil szektor találkozik, és ennek eredményeként egy gazdasági és társadalmi problémákat hatékonyan kezelni képes, a kapitalista fejlődés alternatívájaként megjelenő, harmadik út jön létre.

Az elmúlt két évtizedben a szociális gazdaságról egyre inkább a szolidáris gazdaságra helyeződött a hangsúly főleg Európában és a Latin-Amerikai országokban. A szolidáris gazdaság kereteinek felvázolásakor a szakértők Polányi gazdasági integrációs sémáinak középpontba állításával a gazdasági tevékenységek tágan értelmezett - a piacot, az újraelosztást és a reciprocitás elvét is magában foglaló - modelljét javasolják, s ezzel együtt az eddigi modellekhez képest még határozottabban megkérdőjelezik a gazdaság kapitalista modelljének általános érvényességét. A szolidáris gazdaság értékrendszerének megfelelően a helyi gazdaság fejlesztése már nem korrektív, vagy kiegészítő eleme a globális gazdaságnak, mint a harmadik szektor szociális gazdasága, hanem ökológiai, esélyegyenlőségi, kulturális aspektusokkal megerősödve a lokális rendszerekben építkező, de globális szinten érvényesülő gazdasági, társadalmi ökoszisztéma meghatározó elemévé vált.

A tanulmány célja annak elemzése, hogy a szociális gazdaságtól a szolidáris gazdaságig vezető modellváltás milyen gazdasági, társadalmi és politikai közegben zajlott, $\mathrm{s}$ milyen alapvető értékek változásával járt Európában és Magyarországon. Módszerként az elmúlt három évtized szociális gazdaságára vonatkozó tudományos és politikai diskurzusok elemzését választottuk.

Judit CSOBA: professor, Department of Sociology and Social Policy, Institute of Political Sciences and Sociology, Faculty of Arts, University of Debrecen; Egyetem tér 1., H-432, Debrecen, Hungary; https://orcid.org/0000-0001-5285-521X

KEYWORDS: social economy; solidarity economy; third sector; social cooperative; social enterprise

ABSTRACT: The concept of social economy emerged around the millenium at the intersection of development and employment policies, the market, the public and civil sectors, providing an alternative, third path to capitalist development that is capable of effectively addressing economic and social problems.

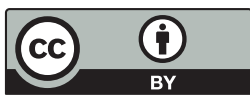


In Europe the concept of social economy has developed over the last 30 years, invariably changing its focus (e.g. nonprofit enterprise, cooperative, social enterprise) but keeping its economic formations that adhere to the capitalist model. Expectations related to the third path model turned out to be futile. The 'third sector' did not become a real alternative to capitalism, rather it has been integrated into the market model in many ways.

Social economy, which emphasized employment and social security guaranteed by the welfare state in the 1990s, has become a model by now emphasizing the self-sustaining role of social enterprises and the individual responsibility of citizens. This performance-based element which focuses on economic sustainability has strengthened over the years, rather than the model aiming at social integration. At the same time, a 'bipolar' transformation can be observed, whereby the market sector in Western countries and the public sector in the majority of the post-socialist countries, especially in Hungary, have flown into the third sector.

Over the past two decades, the concept of solidarity economy has gradually replaced social economy first in Latin American countries and later in Europe as well. The framework of solidarity economy, focuses on Polanyi's economic integration schemes and proposes a broadly interpreted model of economic activities, including the market, redistribution and the principle of reciprocity, thus questioning the general validity of the capitalist model of economy. In this framework the development of the local economy is no longer seen as a corrective or complementary element of global economy, rather as a key component of the economic and social ecosystem, strengthened by ecological, equity-based and cultural aspects that are built in local ecosystems but prevail on a global scale.

The aim of the study is to analyse the economic, social and political environment of the shift from social economy to solidarity economy entailing changes to the fundamental values of social economy. Our methods draw on academic and political discourses of the past three decades about social economy. The analysis pays special attention to territorial differences in the use of key concepts related to social economy. The discussion of international trends focuses on the European model and the way the development of social / solidarity economy in Hungary adheres to European trends.

\section{Bevezető}

A szociális gazdasággal szembeni várakozások az ezredfordulón az Európai Unió országaiban mind határozottabbá váltak. A nemzetközi hatalmi viszonyok átrendeződése, a világméretűvé vált globalizáció és technikai modernizáció a kilencvenes évek elején a centrum országokban foglalkoztatási válsághelyzet kialakulásához vezetett. A piaci és az állami szektor mellett a harmadik szektor megerősítése és a helyi gazdaság fejlesztése alkalmas megoldásnak tűnt a munkaerőpiaci lehetőségek szélesítésére és egy erősebb szociális kohézió megteremtésére (Cambell 1999).

Magyarország az Európia Unióhoz való csatlakozását követően a Regionális Operatív Program (ROP 2004-2006) 3.2 intézkedés 3. komponensében fogalmazta meg a helyi foglalkoztatási kezdeményezések fejlesztésére és megerősítésére irányuló intézkedéseket. Az Országos Foglalkoztatási Közalapítvány a kezdeményezés támogatására egy Regionális Operatív Program Hálózatot (OFA-ROP Hálózat) hozott létre. A Hálózat a központi és regionális irodáin keresztül szakértői támogatást és szakmai tanácsadást nyújtott az Európai Szociális Alap társfinanszírozásával megvalósuló helyi foglalkoztatási projekteknek. Az OFA-ROP Hálózat 
szakértői feladatainak ellátására olyan szakembereket kértek fel, akik a helyi foglalkoztatási kezdeményezések terén az ezredfordulón már mérvadó kutatásokat, fejlesztéseket végeztek. Így lett a szakértői team tagja Frey Mária közgazdász, G. Fekete Éva geográfus, Lévai Márta szakértő, Soltész Anikó közgazdász és Csoba Judit szociológus. A szakértői csoport közös munkájának eredményeként született a Szociális gazdaság kézikönyv (Frey et al. 2007). A kézikönyv összeállításával a szerzők célja az volt, hogy az Európai Unióban az ezredfordulón a helyi fejlesztéseknek keretet kínáló, mind hangsúlyosabbá váló szociális gazdaságról a hazai szakemberek számára egy rövid áttekintést adjanak. A szociális gazdaság fogalmának, az állami és piaci szektorhoz való illeszkedésének, a közösségi vállalkozások alapításának, működési sajátosságainak és jellemző tevékenységeinek elemzésére azért is szükség volt, mert egyfelől a szociális gazdaság hazai jogszabályi, intézményi, szervezeti keretei nem voltak világosak, másfelől pedig az új modellel szembeni várakozások nagyon eltérő érdekrendszerbe ágyazódtak.

A szociális gazdaság hazai kereteit elemző OFA-ROP Hálózatban végzett szakértői tevékenységünk során, számos területen támaszkodhattunk G. Fekete Éva akkor már évtizedes kutatói és fejlesztői tapasztalataira. A kilencvenes évek elején, a Csereháton általa elindított helyi fejlesztési kísérletek (G. Fekete 1990; G. Fekete 1991) az évtized közepére már komplex térségfejlesztési elméletté formálódtak (G. Fekete 1994). Írásainak középpontjában már ekkor olyan kulcsfogalmak álltak, amelyek a szociális gazdaság alappillérei voltak. A lokális gazdaságfejlesztési modelleket elemző tanulmányai mellett elsőként írt a kistérségi, vagy közösségi összefogáson alapuló területfejlesztésről (G. Fekete 1995; G. Fekete 1999a), megírta az alulról vezérelt (bottom-up) vidékfejlesztés kézikönyvét (G. Fekete 1998), és a profitot középpontba állító gazdaságközpontú fejlesztés helyett emberközpontú regionális fejlesztésről beszélt (G. Fekete 1999b).

Mire elkezdtük a közös munkát, ő már tudta, hogy mi a siker titka a kistérségi fejlesztésekben (G. Fekete 2000a), és azt is, hogy mit kell tudni egy térségi menedzsernek (G. Fekete 2000b). Ismerte a szociális földprogramokat (G. Fekete 2003), a tartós munkanélküliség hatékony kezelési módjait (G. Fekete, Velkey 2002) és a leszakadó csoportok felzárkózását támogató kistelepülési önkormányzatok mozgástereit és kényszerpályáit (G. Fekete 2004). Írásaiban elsőként mérlegelte a szociális gazdaság kiépítésének esélyeit Magyarország egyik hátrányos helyzetű régiójában (G. Fekete, Solymári 2004), és az elsők között elemezte a szolidáris gazdaság elméleti és gyakorlati kérdéseit (G. Fekete 2007, 2011). G. Fekete Éva és kutatóműhelye a magyarországi folyamatok elemzése mellett jól ismerte a nemzetközi, ezen belül is a "félperiféria létből" és a poszt-szocialista viszonyokból kiemelkedő, a szocialista örökségből adódó sajátosságokat magukon cipelő kelet-közép-európai modelleket is (G. Fekete 2017, 2018). Kutatásai nem csupán az OFA-ROP Hálózat szakértői műhelyében, hanem az azóta eltelt másfél évtizedben is iránymutatóak voltak és fontos forrásként szolgáltak a jelenlegi írásunk készítésekor. 
Tanulmányunk célja, hogy röviden áttekintse a szociális gazdaság fogalmának az elmúlt 30 évben bekövetkezett tartalomváltozását, s elemezze, hogy a szociális gazdaságtól a szolidáris gazdaságig vezető modellváltás milyen gazdasági, társadalmi, politikai közegben zajlott és milyen, a szociális gazdasághoz kötődő alapvető értékek változásához vezetett.

Elemzésünket a következő kutatási kérdésekre fókuszáltuk:

- Hogyan változott a szociális gazdaság fogalmának tartalma az elmúlt 30 évben az Európai Unió országaiban és Magyarországon? Mikor és miért jelenik meg a szolidáris gazdaság fogalma?

- Milyen hangsúlyváltozások következtek be a vizsgált időszakban a szociális gazdaság társadalmi, gazdasági, politikai szerepét illetően?

- A szociális gazdaság fogalmának és társadalmi szerepének változását hogyan formálták az Európai Unióban illetve Magyarországon érvényesülő gazdasági, politikai és ideológiai tényezők? ${ }^{1}$

A kutatási kérdések vizsgálatakor Foucault (1998) kritikai diskurzuselemzésének (Critical Discourse Analysis) módszerét alkalmaztuk. Az elmúlt három évtized szociális gazdaságra vonatkozó, meghatározó tudományos és politikai elemzéseinek fogalmait, jelentésváltozásait, valamint az európai és hazai szakpolitikai írásokban megjelenő stratégiákat vizsgáltuk. A szociális gazdaság fejlődési szakaszainak bemutatásakor kiemelt szerepet szántunk a magyarországi fejlődési sajátosságok nemzetközi trendekbe ágyazott elemzésének.

\section{Szociális gazdaság vagy szolidáris gazdaság?}

A Szociális gazdaság kézikönyv készítésekor (2004-2006) a szerzők megfogalmazásaiban még nem volt jelentős távolság a szociális gazdaság és a szolidáris gazdaság fogalmak tartalma között. Az akkor megismert nemzetközi szakirodalom szerzőinek többsége is szinonimaként használta a fogalmakat, hangsúlyozva a lokális gazdasághoz kötődő tevékenység társadalmi kohéziós szerepét. Az azóta eltelt 15 évben azonban a szociális gazdaság fogalma a nemzetközi szakirodalomban jelentősen átalakult, és napjainkra a két fogalom önálló jelentéstartalommal bír. Fontos azonban hangsúlyoznunk, hogy nem egy csapásra történő modellváltásról beszélünk, hanem a fogalmak tartalmának folyamatos átalakulásáról. A lassú átalakulás során csaknem észrevétlenül erősödtek meg egyes jelentéstartalmak (például a szociális gazdaság piaci elemeinek erősödése), vagy tűntek el korábban meghatározó értékek (társadalmi kohézió erősítése, vagy a szociális jogok garantálása). Így könnyen előfordul, hogy a szociális és szolidáris gazdaság fogalmakat, illetve a harmadik szektor kifejezést ma is szinonímaként, vagy eltérő tartalommal használják a nemzetközi szervezetek és a hazai és nemzetközi szakirodalom szerzői.

A szociális és szolidáris gazdaság fogalmi rendszerében bekövetkezett változásoknak és azok hazai megnyilvánulási formáinak kutatását G. Fekete Éva és kuta- 
tócsoportja 2014 szeptemberében a „Szociális és szolidáris gazdaság a posztszocialista perifériákon" címü OTKA program keretében indította el, s számos új jelenséggel szembesítette a téma iránt érdeklődő kutatói közösséget. A jelen tanulmány keretében megfogalmazott, a kulcsfogalmak tartalmának tisztázására irányuló meghatározási kísérletek is az általuk elindított gondolatok mentén születtek.

\section{Szociális gazdaság}

A szociális gazdasággal kapcsolatban sokféle gazdasági és társadalmi várakozás, esetenként konkrét megrendelés (például hány millió új munkahelyet kell létrehoznia) fogalmazódott meg az elmúlt három évtized során. A folyamatosan megújuló elvárásokban az eltelt évek alatt számos érdekellentét is kereszteződött. Politikai és gazdasági szereplők, szakértők és laikusok eltérő hangsúllyal jelölték ki a szociális gazdaság célját, s töltötték meg tartalommal a fogalmát, szinonimaként használva a nonprofit szektor, harmadik szektor, a szociális gazdaság, szolidáris gazdaság, szociális vállalkozás, társadalmi vállalkozás megnevezéseket. Az eltérő, olykor egymásnak ellentmondó tartalmi elemek ellenére a szociális gazdaság fogalomnak van néhány, az elmúlt évtizedekben folyamatosan jelen lévő, az interdiszciplináris jellegtől függetlenül érvényesülő stabil eleme:

- a piacgazdaság keretei között valósul meg;

- a piac és az állam mellett harmadik szektorként müködik;

- fogyasztóközeli, helyhez és időhöz kötött tevékenység (lokális gazdaság elsőbbsége a globális gazdasági hálózatokkal szemben);

- a piac és az állam által ki nem elégített szükségletekre kínál innovatív megoldásokat;

- a vertikális struktúrák helyett a horizontális szervezeti formákat erősíti;

- a partnerség elvének képviseletét hangsúlyozza a döntéshozatali és müködési rendszerekben;

- meghatározó szervezeti keretei a nonprofit szervezetek, szövetkezetek, segélyegyletek (G. Fekete, Solymári 2004; Frey et al. 2007; Lipták et al. 2019).

Jóllehet a szociális gazdaságra vonatkozó mérvadó meghatározások többsége mindezeket tartalmazza, a hangsúlyok gyakran eltérőek, évtizedenként változnak.

\section{A kilencvenes évek: a föszerep a foglalkoztatásbövitő harmadik szektoré}

A kilencvenes évek második felében a szociális gazdaság megerősítésére irányuló kísérletek jól illeszkedtek a szociáldemokrácia megreformálására és egy új jóléti modell kialakítására irányuló törekvésekhez. A neoliberális alapokon nyugvó gazdaságpolitika és a jóléti állam válsága új elméleti modellt hozott felszínre, a „harmadik út” (Giddens 1998) modelljét. A reformok kezdeményezői a piaci és társadalmi érdekek összebékítésére törekedtek (Csoba 2017). Az addig uralkodó neoliberális áramlattal szemben a szociáldemokrácia megreformálására és egy új 
gazdasági és jóléti modell kialakítására irányuló törekvéseket az is erősítette, hogy Európa meghatározó országaiban a szociáldemokrata, illetve baloldali politikai erők kerültek vezető pozícióba (Tony Blair 1997-2007; Gerhard Schröder 1998-2005; Wim Kok 1994-2002; Poul Nyrup Rasmussen 1993-2001; Lionel Jospin 1997-2002).

A harmadik út modell megvalósítására irányuló törekvéseket a kilencvenes évek közepétől a mérvadó nemzetközi szervezetek is támogatták. A kezdeményezés összhangban volt az OECD új irányelveivel: a neoliberális étékeket háttérbe szorítva a jóléti kiadásokról, mint társadalmi befektetésről, új szociálpolitikai menetrendről és új foglalkoztatási stratégiáról tárgyaltak. A korszak két meghatározó dokumentumában (The OECD Job Strategy OECD 1997a és a The New Social Policy Agenda OECD 1997b) a gazdasági és szociális területet azonos súllyal és jelentőséggel, egymást feltételező területetként tárgyalták.

A harmadik út modellben kulcsszerepet játszó harmadik szektor megerősítésére irányuló fejlesztésekben kiemelt szerepe volt az Európai Uniónak. A domináns politikai erővonalaknak megfelelően az EU nyitott volt azokra a harmadik utas kísérletekre, amelyekben a szociális védelmet a gazdasági növekedéssel kívánták összebékíteni. Az 1993 óta tartó luxemburgi folyamat kiteljesedéseként 1997-ben az Amszterdami Szerződésben új cikkeket (125-130. cikkek) iktattak be az EU-tagállamok foglalkoztatási stratégiájának összehangolt fejlesztése („nyitott koordináció”) érdekében. Ezt követően az Unió tagállamai által közösen megfogalmazott foglalkoztatáspolitikai irányelvek (employment policy guidelines) között minden évben szerepelt a szociális gazdaság, mint a helyi foglalkoztatás fejlesztésének eszköze. A tagállamok az irányelveknek megfelelően a nemzeti akcióterveikben fogalmazták meg a szociális gazdaság fejlesztésére irányuló intézkedéseiket.

Bár a szociális gazdaság fogalma Franciaországban a hetvenes évek óta zajló önszerveződésnek köszönhetően a nyolcvanas évek elejére Európában is megjelent, ${ }^{2}$ széles körben ismertté az Európai Bizottság (Bizottság) által 1993-ban publikált Növekedés, Versenyképesség, Foglalkoztatás című Fehér Könyv (EC 1993) után vált. A Bizottság úgy vélte, hogy a kilencvenes évek elején drasztikus mértékben növekvő munkanélküliséggel szemben a háztartások által igénybe vehető helyi szolgáltatások piaccá szervezése a szociális gazdaság keretein belül kiváló megoldás lenne a foglalkoztatás bővítésére. Megítélése szerint a piacgazdaság keretei között, de azoktól világosan elkülönítve, az első és második szektor által kielégítetlen szükségletekre fókuszálva, a helyi szükségleteket és szereplőket előtérbe helyezve szerveződne az új munkahelyeket teremtő szociális gazdaság, főként a közösségi, az életkörülményeket javító szolgáltatások, a szabadidős, kulturális, audiovizuális tevékenységek és a környezetvédelmi szolgáltatások terén (EC 1995). Az EU az Európai Szociális Alap finanszírozásával forrást is teremtett a szektor bővítésének támogatására. Az 1995-ben induló kísérleti programok (ADAPT, EMPLOYMENT) középpontjában is elsődlegesen a foglalkoztatás bővítése és a megváltozott munkaerőpiaci körülményekhez való hatékony alkalmazkodás 
állt. Ebbe a sorba illeszkedett az 1997-ben indított „Harmadik szektor és foglalkoztatás" (Third System and Employment Programme) (TSEP 1999) címü két éves program, amely a szociális gazdaság munkahelyteremtő és helyi gazdaságfejlesztő képességét elemezte, és számos modellkísérleti programot támogatott. A kísérleti projektekre alapozva a szakértők úgy vélték, hogy Európában a harmadik szektor a szolgáltatások fejlesztése terén legalább három millió új munkahely létesítésére lenne képes (Campbell 2000). Mindezek eredményeként az Amszterdami Szerződés elfogadását követően a Luxemburgi Csúcson 1997-ben létrehozott Európai Foglalkoztatási Stratégia is a foglalkoztatás növelésében jelölte ki a szociális gazdaság helyét (EC 1997).

A szakértők és politikusok többsége támogatta a várakozásaik szerint a munkanélküliség mérséklését és a humánerőforrás fejlesztését szolgáló szociális gazdaság bővítését, melynek legfőbb célja az volt, hogy a kirekesztettség által veszélyzetett személyek számára munkalehetőséget biztosítson. Castel (1998 [1995]) azonban már a Foglalkoztatási Stratégia elfogadását megelőzően kritikusan szemlélte a harmadik szektor foglalkoztatásbővítő szerepével kapcsolatban megfogalmazott várakozásokat. „Létezik ... a normális foglalkoztatás és a segélyezés, a társadalmi beillesztés és a szakmai átképzés, a piaci szektor és a támogatott szektor közé beékelve egy olyan „harmadik szektor”, melyet olykor „szociális gazdaságnak” hívnak. E tevékenységek terjedőfélben vannak, legkivált a munkanélküliség „,szociális” kezeléséből adódóan, amelynek kapcsán olykor nehéz eldönteni, hogy a kitüzött cél az újbóli munkához juttatás-e, vagy pedig olyan helyzet rögzítése, amely éppenséggel „félúton” van a munka és a segélyezés között. Ezek az eredmények, amelyek 1993-ban 400 ezer embert érintettek, s amelyek hajlamosak a klasszikus munkaerőpiac önálló szegmensévé válni, hasznosnak bizonyulnak egy katasztrófahelyzetben. Az azonban merő eufemizmus, ha 'foglalkoztatáspolitikának' minősítjük őket" (Castel 1998, 406.).

A kilencvenes években a szociális gazdaság foglalkoztatáspolitikai szerepe mellett abban a kérdésben sem volt teljes az egyetértés, hogy hol húzzák meg a szociális gazdaság határait. A legáltalánosabban elfogadott értelmezés szerint a szociális gazdaság a harmadik szektor (vagyis a nem állami és nem piaci szerveződésü) szervezetek komplex rendszere. Az európai értelmezés szerint a szociális gazdaság a harmadik szektornál tágabb, s a piaci szövetkezeteket éppúgy magában foglalta, mint az állam által is támogatott segélyegyleteket. ${ }^{3}$

A brit értelmezés szerint a harmadik szektor még ennél is szélesebb, és a karitatív alapon működő szervezeteket, a közösségi gazdaságot, az informális gazdaságot, a családi, önellátó tevékenységeket is tartalmazó árnyékgazdaságot is magában foglalja (Conscise 2000).

Az elméleti viták ellenére a kilencvenes években a legtöbb európai országban a közösségi/állami támogatást is igénybe vevő, vállalkozói tevékenységet végző nonprofit szervezetek álltak a szociális gazdaság középpontjában. A legszélesebb körben elfogadott azonosító kritérium pedig a haszon magáncélú felhasználásának korlátozása volt (Defourny 2001). 
A szociális gazdaság fogalmához ebben az időben Magyarországon számos félreértés, illetve mítosz kötődött. A közvélemény a szociális gazdaság szervezeteit többnyire a karitatív céllal müködő önkéntes szervezetekkel azonosította, vagy a sorsközösségben élők önsegítési formájaként képzelte el. Az elnevezésből adódóan a szervezetek tevékenységét többnyire szociális szolgáltatáshoz kötötték, melynek forrását nem bevételt termelő vállalkozói tevékenység, hanem pályázat, vagy központi, illetve magánforrásból származó támogatás jelentette (Csoba 2007). A közvéleménnyel szemben a szakértők a foglalkoztatási célú nonprofit szervezeteket sorolták ide, melyek száma a kilencvenes évek végén közel 200 volt (Frey 2001; SZITI 2006). ${ }^{4}$ A szervezetek múködési forrásai azonban itt sem az általuk szervezett vállalkozások bevételéből, hanem támogatásából származtak. A támogatás egyik meghatározó forrása ebben az időben az 1992-ben alapított Országos Foglalkoztatási Alapítvány által évente kiírt pályázat volt. G. Fekete és Solymári a szociális vállalkozások körébe sorolta a kilencvenes évek elején indult szociális földprogramot is, amely a legszegényebb településeket érintette (G. Fekete, Solymári 2004, 37.).

A szociális gazdaság előzményeként említhetjük még azokat a lokális gazdaságfejlesztési kísérleteket, amelyek a közösségi gazdálkodás kereteiben megvalósuló, alulról jövő kezdeményezéseket karolták fel. Ezekben a modellekben is sokkal meghatározóbb volt a támogatási elem (jóléti redisztribúció), mint a gazdálkodás eredményeként elért saját jövedelem (G. Fekete 1990, 1991, 1994, 1998).

A kilencvenes években a többnyire „felülről” kezdeményezett és támogatott hazai modellek azonban sok vonatkozásban különböztek azoktól a társadalmi szerveződésektől, amelyeket szociális gazdaságként lehetne azonosítani. Ennek hátterében G. Fekete szerint az állt, hogy „Kelet-Közép-Európában a 80 -as évek végéig gyakorlatilag nem volt lehetőség a társadalmi gazdaság megerősödésére. Míg a nyugati társadalmakban a jóléti állam altatta el a társadalmi öngondoskodást, Kelet-Közép-Európában a mindent kontrollálni akaró államszocializmus hatalmi törekvései blokkolták a társadalmi gazdaság alapját jelentő társadalmi szerveződéseket" (G. Fekete 2018,110.).

\section{$A z$ új évezred elsö évtizede: a szövetkezeti mozgalom és a neoliberális értékek térhódítása a harmadik szektorban}

Az ezredfordulót követően a szociális gazdasággal kapcsolatos célok, szervezeti keretek és várakozások némiképpen módosultak. A változáshoz jelentős mértékben hozzájárultak az új évezred elején meghatározóvá vált politikai és gazdasági tényezők. Az európai politikai palettán a baloldali erők súlyának csökkenésével a humánerőforrásba való befektetést szorgalmazó harmadik utas kísérletek háttérbe szorultak, s helyüket a liberális 'work first' modellek vették át. Ez a modell a „humántőke" azonnali munkaerőpiaci értékesítését szorgalmazta, s az állam humánero"forrásba történő befektetéseit, széleskörü szerepvállalását nem tartotta indokoltnak. 
A szociális jogok helyett mind határozottabban a kötelezettségek és a feltételekhez rögzített jóléti ellátások kerültek előtérbe, s a támogatások visszaszorulásával felértékelődött a piaci jelenlét és eredményesség. Az újra erőre kapó neoliberális értékek szerint a gazdaság fejlődésének feltétele az átfogó dereguláció, így a foglalkoztatáspolitikában és a jóléti intézmények és szolgáltatások működtetésében a széles körü állami szerepvállalás csökkentését $\mathrm{s}$ az egyéni felelősségvállalás növelését hirdették (Conill et al. 2012; Csoba 2017).

A szociális gazdaságban a korábban jelentős közösségi/állami támogatást elvető, vállalkozói tevékenységet végző nonprofit szervezetek köre kibővült és a hangsúly a foglalkoztatási elemről folyamatosan áthelyeződött a helyi gazdaságfejlesztésre, ${ }^{5}$ melynek meghatározó szervezeti kerete a szövetkezet volt (Defourny 2001). A mérvadó nemzetközi szervezetek is támogatták a szövetkezetek beillesztését a társadalmi felzárkóztatás és foglalkoztatásbővítés fókuszába. Az ENSZ 1999-ben megjelentette a „Szövetkezetek szerepe a társadalmi fejlődésben”6 című határozatát, az Európai Bizottság 2002-ben adta ki a „Szövetkezetek a vállalkozóbarát Európában"7 című dokumentumát, amely az Európai Szövetkezetre vonatkozó határozattervezetet is tartalmazta. Ebben a dokumentumban a szociális gazdaság kereteinek szélesítése mellett foglaltak állást. „A szövetkezeteket és a szélesebb körű szociális gazdaságot jelenleg nyilvánvalóan bevontuk az Európai Foglalkoztatási Stratégia fó áramába" (Futó 2004,16.). 2002-ben az Európai Tanács közzé tette az „Európai szövetkezetrool” szóló rendeletét, ${ }^{8}$ az ILO pedig az egész világra kiterjedő ajánlást fogadott el „A szövetkezetek támogatásáról”. ${ }^{9}$

Ez utóbbi dokumentumban csak utalás történik a szociális gazdaságra, a szövetkezeteket azonban határozottan megjeleníti. A szociális szövetkezetek fejlesztésének támogatására az EU jelentős forrásokat különített el, amelyeket a 2004. évi bővülést követően az új tagállamok számára is hozzáférhetővé tett. A szociális szövetkezetek száma a törvényi szabályozást követően az Európai Szociális Alapból származó Operatív Programoknak köszönhetően a csatlakozást követő első években jelentősen megnövekedett (Ciepielewska, Kowalik 2015; G. Fekete, Lipták 2014).

A szövetkezeti alapon szerveződő modell azonban több komoly kihívással szembesült. A szociális szövetkezetek elsőként megjelenő olasz modellje (Defourny 2014) mögött még az az elképzelés állt, hogy civilek hozzák létre, az államhatalomtól függetlenül hoz döntéseket, de az államnak nyújtott szolgáltatásaiért cserébe - mivel alapvetően olyan területeken nyújt szolgáltatást, amelyet a piaci szereplők nem tartanak kifizetődőnek - állami (központi vagy regionális) támogatást kap. A deregulációs folyamatnak és a jóléti szolgáltatások fokozatos visszavonulásának köszönhetően azonban egyre erőteljesebben merült fel az önfenntartás gondolata, s a szövetkezetek esetében a „közösségi” elem mellett mind nagyobb hangsúlyt kapott a „piaci” elem. Egy meghatározott idejű (3-5 év) támogatást követően a legtöbb országban a szövetkezeteknek önfenntartóvá kellett válniuk. Ez alapvetően két szempontból jelentett problémát. Egyfelől a fó- 
ként támogatásra épülő nonprofit foglalkoztatási társaságokkal szemben a szövetkezetekben a tagok foglalkoztatása és megélhetésének biztosítása nem átmeneti időre szól. Másfelől a normál vállalkozásoktól a szövetkezetek/szociális szövetkezetek abban különböznek, hogy a hátrányos helyzetủ térségekben, vagy kistelepülésen élő, a nyílt munkaerőpiacon hátrányt szenvedő, tartósan munka nélkül lévő, vagy rossz munkaerőpiaci pozícióval (kor, végzettség, egészségi állapot stb.) rendelkező személyek foglalkoztatásba vonását vállalják. Komoly nehézség azonban, hogy a ,... szövetkezet nonprofitnak számít, mivel nem törekszik profitszerzésre, a tevékenysége nyomán keletkező eredményből csak korlátozott, a szövetkezetben végzett tevékenység mennyiségével arányos részesedést fizet a tagoknak, ha egyáltalán fizet" (G. Fekete, Solymári 2004, 37.). A létrejött szövetkezetek támogatás nélküli hosszú távú fenntarthatósága ilyen feltételek mellett erősen kérdéses.

Magyarországon a szociális gazdaság fogalmának megjelenése és szélesebb körű ismertté válása az Európai Unióhoz való csatlakozáshoz köthető. Az évtized közepéig a szociális gazdaság kifejezést főleg a szakpolitikai döntéshozók és a terület kutatói használták (Ferge 1991; Frey 1997, 1999; NKE 2001; Futó et al. 2005). Olyan helyi kezdeményezésnek tekintették amelyek „célja a nehezen elhelyezhető emberek integrálása a munka világába, foglalkoztatást, szakmai tudásuk fejlesztését és tanácsadást kínálva számukra....[A szociális gazdaság szervezetei] új munkahelyeket teremtenek, jövedelmet generálnak és az a céljuk, hogy idővel önfinanszírozóvá váljanak (...). Célcsoportjukba tartoznak a tartós munkanélküliek, az elhelyezkedési nehézséggel küzdő pályakezdő fiatalok, a gondozási kötelezettséggel terhelt nők, az idős és fogyatékossággal élő emberek és a szociális beilleszkedési zavarokkal küzdő személyek" (Frey et al. 2007, 23.). A szociális gazdaság hangsúlya Magyarországon - az európai trendekhez viszonyítva - némi fáziskéséssel elsőként a foglalkoztatási elemre helyeződött, s a munkahelyteremtés továbbra is az elsődleges szempont volt. G. Fekete megállapítása szerint a szociális gazdaság szervezeteinek fö szerepe ebben az időben az állami szociálpolitika hiányosságaiból eredő problémák megoldása lett (G. Fekete et al. 2018, 119.).

A szerveződő szociális gazdaság foglalkoztatási fókuszát igazolja a fentieken túl az is, hogy Foglalkoztatáspolitikai és Munkaügyi Minisztérium kezdeményezésére és évi 60-80 millió forintos támogatásával, az OFA szervezésében már az évtized elején elkezdődött a foglalkoztatási célú nonprofit szervezetek szakmai felkészítő munkája a csatlakozást követő szerepvállalásra (OFA/EU-TREND program 2003; OFA/EU HÁLó 2004 program). A felkészítő munkát segítette a Civil Foglalkoztatási Műhely, valamint a Regionális Foglalkoztatásfejlesztési Civil Klubok hálózata (Futó et al. 2005, 41.).

A civil szervezetekre alapozott foglalkoztatásfejlesztésen túl azonban ,a szociális gazdaság koncepciója kevésbé elterjedt volt” (G. Fekete 2018, 115.), s problémát okozott az is, hogy „a kormányzati részről nem konkretizálódott, a magyar 
állam milyen szerepet szán a szociális gazdaságnak" (Futó et al. 2005, 80.). Ennek megfelelően nem volt egyértelmű feladatmeghatározás és munkamegosztás az egyes szereplők között. Hiányoztak továbbá az egyértelmü finanszírozási és jogszabályi feltételek is. A civil szervezetekre alapozott foglalkoztatásfejlesztés további nehézsége a szervezetek forrásfüggősége volt. A szociális gazdaság programjainak létrehozásában és működtetésében az évtized közepéig meghatározó szerepet játszó civil szervezetek a pályázatok és támogatások útján megszerzett forrásokat használták fel, de minimális volt a piaci érintettségük (Tóth et al. 2011).

Az Európai Unióhoz való csatlakozást követően a fentieknek köszönhetően a szakpolitika alakítói, de a kedvezményezett szervezetek körében is gyorsan ismertté és széles körben támogatottá vált a szociális szövetkezeti modell,10 amelyben a direkt foglalkoztatási elemről a hangsúly a helyi gazdaság fejlesztésére és a saját bevételt ígérő vállalkozói tevékenységre helyződött. A 2006. évi. X. törvény megteremtette a szövetkezetek létrehozásának jogi kereteit, s a bőkezű támogatásnak köszönhetően a következő években a szervezetek száma látványosan nőtt. ${ }^{11}$

A szociális gazdaság gyorsan bővülő új szervezeti kerete azonban Magyarországon is számos nehézséggel szembesült. Minimális tőkével rendelkező szervezetek tucatjai jöttek létre a források igénybevételére, $s$ a tőkehiány mellett további deficitek (pl. szaktudás, vállalkozói tapasztalatok és piaci kapcsolatok hiánya, tapasztalatlanság a demokratikus szervezetei keretek működtetésében) is nehezítették a szövetkezetek működését, fenntarthatóságának biztosítását. „Normatív alapú támogatás vagy hosszú távú adókedvezmények helyett projekt-alapú finanszírozásban részesülnek. A periferizálódó területek kihívásai azonban hosszú távú stratégiával oldhatóak meg, amelynek része kell hogy legyen a pénzügyi biztonság is" (G. Fekete 2017, 25.).

A szociális szövetkezetek létrehozásában és működtetésében eleinte az új forrást igénybe vevő nonprofit szervezetek, majd a működési feltételek változásával az évtized végétől egyre inkább az önkormányzatok játszottak meghatározó szerepet (Keller, Bódis 2012; Csoba 2015). A 2007-2009-es támogatási periódusban a többnyire nonprofit szervezetek kezdeményezésével létrehozott szociális szövetkezetek jelentős része a projektalapú támogatás lejárta után már nem volt aktív. 2015-ben az 57 szociális szövetkezetből csupán 5 szervezet működött (Mihály 2018, 236.). A hosszú évek során „pályázati forrásfüggőségre" szocializált szervezetek többsége nem érte meg a saját bevételre épülő „önfenntartó” szakaszt. A szociális szövetkezet hazai kísérlete igazolta: önfenntartó gazdasági vállalkozást működtetni a leghátrányosabb helyzetű lokális szereplőkkel nem lehet. A fenntartható működés feltételeinek hiányában - jogi, pénzügyi, piaci stb. garanciák - a hátrányos helyzetü célcsoport körében a rövid ciklusú fejlesztés nem vezethet eredményre (G. Fekete, Lipták 2014). 


\section{Napjaink társadalmi vállalkozásai}

A 2008. évi gazdasági válságot követően a munkanélküliség, a szegénység és a társadalmi kirekesztés korábban nem ismert méreteket öltött. A jóléti államokra egyre nagyobb nyomás nehezedett, a válság okozta bizonytalanság felerősítette a jelenlegi gazdasági és társadalmi renddel kapcsolatos kritikákat. Megoldásként két egymással ellentétes fejlesztési irány körvonalazódott. A neoliberális értékekre épülő fejlesztési irány a társadalmi integráció, szociális kohézió, és az életminőség javulásának hangsúlyozása helyett az önfenntartásra vonatkozó elvárást emelte fókuszba, a munkahelyteremtés-, a növekedés- és befektetésközpontú stratégiában a piaci befektetők támogatásának elsődlegességét hirdette. A másik - sok esetben kapitalizmusellenes elemeket is tartalmazó - modell a termelési és elosztási formák - pl. alapjövedelem - átalakítását tüzte ki célul. Az alternatív szerveződési formák között kiemelt helyet foglal el a társadalmi vállalkozások népszerűsége, globális elterjedése is (Conill et al. 2012; Laville 2010; Hubai 2017; Mihály 2017; Kiss 2018).

Az Európai Bizottság viszonylag későn szembesült a válság utáni új kihívásokkal. 2009-ben az Európai Parlament szociális gazdaságról szóló állásfoglalása (Toia-jelentés) a szociális gazdaság megerősítése mellett szólt. Az európai tudományos világ 2010 októberében közzétette „A szavaktól a tettekig: A szövetkezeti és szociális vállalkozások támogatása a befogadóbb, fenntartható és prosperáló Európa érdekében" című nyílt levelét. A Bizottság végül 2011. február 23-án közleményt adott ki a Tanácsnak, az Európai Parlamentnek, az Európai Gazdasági és Szociális Bizottságnak és a Régiók Bizottságának, amelyben felülvizsgálta az európai kisvállalkozói intézkedéscsomagot (EC 2011a). A közlemény elemezte a szociális gazdaság szerepét és arra kötelezte az Európai Bizottságot, hogy 2011 végéig elfogadja a „Kezdeményezés a szociális vállalkozásért” programot (EC 2011b). Ezt követően a társadalmi vállalkozásokat a szociális gazdaság meghatározó szervezetének tekintik (CIRIEC 2012, 59.).

2011-et követően a mérvadó EU-dokumentumok egyre ritkábban említik a szociális gazdaságot, helyette a társadalmi vállalkozások kerülnek a diskurzusok és stratégiai dokumentumok középpontjába. Az Európai Unió országai közül 2019-ig 23 tagállamban született jogszabály a társadalmi vállalkozási forma elismerésére, és tizenhétben készült külön szakpolitikai stratégia a szektor fejlesztésére, szociálpolitikai szerepének formalizálására (EC 2020). A szociális gazdaság új köntösben jelent meg a posztszocialista országokban is. Például Csehországban, Szlovéniában és Litvániában a munkaerőpiaci integrációt segítő társadalmi vállalkozás a szociális gazdaság hivatalosan elismert és politikai szempontból számon tartott szervezete (Dohnalová et al. 2016; Moskvina 2013; Podmenik et al. 2017).

A stratégiai dokumentumok társadalmi vállalkozásokra vonatkozó definiciójával kapcsolatban azonban viszonylag hamar több kritika is megfogalmazódott. Az alkalmazott fogalmak ugyanis nagyon általánosak voltak, s a legkülönfélébb 
elvárások egyidejű megjelenését szolgálták. „Az ENSZ Fejlesztési Program a gyenge jóléti államokkal és korlátozott szociális biztonsági hálóval rendelkező társadalmak alulról szerveződő védelmi rendszerét, a szociálpolitika kialakításának egyik eszközét látja a társadalmi vállalkozásokban (Borzaga et al. 2008), míg a Nemzetközi Munkaügyi Hivatal a gazdaság kifehérítésében, a munkajogok megteremtésében, valamint az emberközpontú technológiai fejlődés biztosításában látja a kettős célrendszerrel rendelkező szervezetek fontosságát (Fonteneau et al. 2011; Borzaga et al. 2017). Az Európai Bizottság interpretációjában pedig mint a szociális piacgazdaság hagyományaiba ágyazott, befogadó növekedés szervezeti megnyilvánulása jelenik meg (EC 2013)" (Hubai 2019, 5.).

Hubai (2016) - Defourny és Nyssens (2014) elméletére hivatkozva - megkülönbözteti a társadalmi vállalkozás amerikai és európai megközelítését. Az amerikai modellben a jövedelemszerző irányzat (earned income school) és a társadalmi innovációs megközelítés (social innovation school) a meghatározó. Ez az irányzat ennek megfelelően a piaci tevékenységet és a társadalmi vállalkozó szerepét hangsúlyozza és erős kapitalista szemléletmódot képvisel. A nyugat-európai irányzat nagyobb hangsúlyt fektet a társadalmi és gazdasági célok egyensúlyát biztosító intézményi garanciák meghatározására, valamint a részvételt hangsúlyozó politikai dimenzióra. Ugyanakkor célszerủ arra felfigyelni, hogy a nyugateurópai modellben is a korábbiaknál hangsúlyosabban kap szerepet a piaci jövedelem, valamint az innovációkra vonatkozó elvárás.

A társadalmi vállalkozás fogalmi kereteinek rugalmassága a kritikusok véleménye szerint nem csupán a legkülönfélébb célok megfogalmazását, de igen eltérő kormányzati és ideológiai szándékok igazolását is lehetővé teszi (Teasdale 2012). Laville (2014) szerint a társadalmi vállalkozások túlságosan amorf megfogalmazása, a szervezeti gyakorlatok rugalmas elismerése egyenesen a kapitalizmus re-legitimációját, a piaci értékek elsődlegességének elismerését, a domináns piaci logika térnyerését szolgálja a szociális gazdaság keratein belül. A társadalmi vállalkozás puha definiciója mindemellett még azt is lehetővé teszi, hogy pozitív értéktartalommal felerősítve támogassa a piaci viselkedés és a fogyasztói kultúra terjesztésének új hullámait (Laville 2015; McMurtry 2018).

Mindezek eredményeként a szociális gazdaság definiálása társadalmi vállalkozás formájában a vállalkozás paramétereinek elsődlegességéből indul ki (Coraggio et al. 2015). A 2014. évi Strasbourgi Nyilatkozat ${ }^{12}$ szerint a szociális vállalkozók mint a változás ügynökei már nem csupán csoportosan, közösségi formában megvalósuló vállalkozásként, hanem egyénileg is törekedhetnek az emberek, illetve közösségek életének jobbítására. A társadalmi vállalkozás pedig már nem kizárólag a nonprofit jellegű tevékenységeket foglalja magában, hanem valamennyi olyan vállalkozást is, ami a társadalmi vállalkozások alapcéljait elfogadja, és a profitot legtöbbször visszaforgatja a szociális célok elérése érdekében.

A változások jól tükröződnek Defourny és Nyssens (2016) társadalmi vállalkozásokra vonatkozó tipológiájában. A szerzők négy meghatározó társadalmi vál- 
lakozási formát különítenek el: vállakozó nonprofit szervezetek (ENP- Entrepreneurial nonprofit); szociális szövetkezetek (SC - Social cooperative); forprofit társadalmi vállalkozások (SB - Social business); közszektorbeli társadalmi vállalkozások (PSE - Public sector social enterprise).

A társadalmi vállalkozás mindezeknek megfelelően a piaci szektor múködési rendjéhez közeledve fokozatosan elveszíti harmadik szektor jellegét, s a piaci és társadalmi vállalkozások közötti határok kijelölése a hibrid modellekben egyre nagyobb nehézséget okoz (Defourny, Nyssens 2014).

A széles körben elfogadott definíció szerint a társadalmi vállalkozások társadalmi célok érdekében piaci tevékenységet folytatnak, a munkaerőfelvételnél és a bérmeghatározásnál a piaci szervezetekhez képest jobban érvényesítik a társadalmi szempontokat, a civil szervezetekhez képest a piaci jelenlétnek köszönhetően nagyobb pénzügyi stabilitással bírnak, a munkafeltételek az elsődleges munkaerőpiaci körülményekhez hasonlítanak, valamint az állami foglalkoztatáspolitikai programoknál komplexebb (képzések, szociális szolgáltatások), és méreteikben kisebb beavatkozási gyakorlatot követnek (Tortia 2010; Depedri 2010; Borzaga, Depedri 2013; Hubai 2016; Siposné Nádori 2019). A társadalmi vállalkozást azonosító, a piaci vállalkozásoktól elválasztó karaktervonások azonban nem objektív kritériumok. Milyen mértékegységgel mérhető például, hogy a társadalmi vállalkozások esetében ,jobban érvényesülnek a társadalmi szempontok"? Milyen szempontból jelent például előnyt, hogy a társadalmi vállalkozás munkakörülményei jobban hasonlítanak a piaci körülményekhez, ha a célcsoport az elsődleges munkaerőpiacról épp azért esett ki, mert a piaci körülményekhez nem tudott alkalmazkodni?

A társadalmi vállalkozások meghatározását illetően Magyarországon is különböző megközelítések léteznek. Egyes szerzők nagyobb hangsúlyt helyeznek a társadalmi és civil dimenziókra, kiemelve a nonprofit jelleget (Petheő 2009), mások a befogadó döntéshozatali mechanizmusokat és a foglalkoztatásba vonás fontosságát emelik ki (G. Fekete 2007), és van, aki a gazdasági fenntarthatóságra helyezi a hangsúlyt (Tóth et al. 2011; G. Fekete et al. 2018, 122.). A társadalmi vállalkozásokra vonatkozó, az Európai Bizottság számára készült magyar országjelentésben a szerzők kiemelik, hogy a ,... jogi formákról nincs konszenzus, illetve külön törvény sem szabályozza a társadalmi vállalkozásokat, amelyek bármilyen jogi formában működhetnek" (Európai Bizottság 2019, 10.).

A 2014-2020-as időszakra vonatkozó új magyar Partnerségi Megállapodás (Miniszterelnökség 2014) a társadalmi vállalkozások támogatását kifejezett célként írja le. Az egyik első hivatalos szakpolitikai dokumentumban ${ }^{13}$ megtalálható definíció szerint: „,ársadalmi vállalkozásnak tekinthetőek azon nonprofit és civil szervezetek, amelyek társadalmi célkitűzéseik mellett üzleti területen megvalósítható célkitűzésekkel is rendelkeznek, gazdálkodásuk eredményét a társadalmi cél érdekében visszaforgatják, költségvetésükben és szervezeti múködésükben érvényesítik a részvételen alapuló döntéshozatal elvét" (NGM 2015, 6.). 
A felhívás egyértelművé teszi, hogy a társadalmi vállalkozás fogalma Magyarországon még nem nyitott a piaci szervezetek felé. Mihály (2018) szerint a társadalmi vállalkozás fogalom itt többnyire szociális szövetkezetet jelent. Ezt erősíti az Európai Bizottságnak készített szakmai jelentés is, amely a támogatásért pályázó társadalmi vállalkozások online előminősítő rendszere - PiacTárs - alapján összegzi, hogy 2018-ban a 212 regisztrált szervezetből 110 volt szociális szövetkezet, 40 nonprofit gazdasági társaság, 35 egyesület, 26 alapítvány és 1 egyházi szervezet (Európai Bizottság 2019, 44.).

Az adatok alapján levonhatnánk a következtetést, hogy Magyarországon a szociális gazdaság - a társadalmi vállalkozások szervezeti összetételét tekintve - megőrizte harmadik szektor jellegét, hiszen döntően szociális szövetkezetek és nonprofit szervezetek tevékenykednek a szektorban. Következtetésünk azonban nem lenne maradéktalanul helytálló. Egyfelől ugyanis az utóbbi években folyamatosan jelennek meg a szektorhatáron elhelyezkedő, a piaci érdekeket mind határozottabban képviselő hibrid szervezetek (Repisky, Tóth 2019; Matolai, Révész 2020). Másfelől a szociális szövetkezetek keretfeltételeinek átalakításával az állam a ,... poszt-szocialista államok civilekkel szembeni, ... részint az anyagi biztosítékok hiányából fakadó bizalmatlansága..." (G. Fekete 2018,113.) miatt korlátozza a nonprofit szektor szereplőinek működését, s folyamatosan „államosítja” a harmadik szektort. ${ }^{14}$

Annak ellenére, hogy a szociális gazdaság hazai kiépítésekor a szociális szövetkezetek mind gazdasági, mind társadalmi szempontból a legígéretesebb társadalmi innovációnak tűntek, a szövetkezetek legfőbb jellemzőit rögzítő Rochdale-i és a manchesteri elvek, a tagság önkéntessége és nyitottsága, az autonómia és függetlenség, valamint a demokratikus tagi ellenőrzés és a közösségi felelősség a jogszabályi változások eredményeként eltűnnek. Az önkormányzati felügyelettel és tulajdonnal gazdálkodó szociális szövetkezetek használják az Európai Unió szociális gazdaság fejlesztésére szánt támogatásainak többségét, és képezik az elvileg a harmadik szektorban megjelenő társadalmi vállalkozások jelentős részét (G. Fekete, Lipták 2014; G. Fekete et. al 2018; Mihály 2018; Európai Bizottság 2019).

Nem csupán a szociális szövetkezetek, hanem a nonprofit szervezetek esetében is megfigyelhetjük ezt a törekvést. Különösen 2010 után jellemző, hogy a fejlesztés- és foglalkoztatáspolitika intézményrendszere leegyszerűsödött, a szereplők korábbi sokszínűsége megszűnt, a központi állam a standard, ,felülről” protokollszerűen ellenőrizhető szervezeti és intézményi formákat támogatja. A szubszidiaritás és partnerség elvét figyelmen kívül hagyva, a központi állam által finanszírozott közfoglalkoztatási programok váltak a helyi foglalkoztatásbővítés fó eszközévé (Keller et al. 2016, 197.).

Jóllehet a szociális gazdaságot a szakpolitikusok és szakértők többsége napjainkban is a profitorientált első, és a közszférához kapcsolódó második gazdaságot kiegészítő harmadik szektorhoz sorolja, harmadik szektor jellege az utóbbi 
években Magyarországon az „államosítási”, az európai országok többségében pedig a „piacosítási” törekvések miatt megkérdőjeleződik.

Az európai társadalmi vállalkozások terén megfigyelhető változások arra hívják fel a figyelmet, hogy 2010 után a szociális gazdaság erőteljesen elindult a piaci szektor felé. Megnyitotta határait, feladta (legalábbis több szempontból fellazította) közösségi vállalkozás jellegét, és már a nonprofit elvárást sem írja elő. A szociális gazdaság ma olyan, elvileg nem kapitalista vállalkozásokból álló szervezetek összessége, amelyek sikerességét a piacgazdaságba való integráció-

1. táblázat: A szociális gazdaság változása az elmúlt három évtizedben Európában

Changes of social economy in Europe since 1990

1990-2000

2001-2008

2009-napjainkig

\begin{tabular}{|c|c|c|c|}
\hline A fó cél & $\begin{array}{l}\text { A foglalkoztatás ke- } \\
\text { reteinek megteremtése } \\
\text { az alternatív (támoga- } \\
\text { tott) munkaerőpiacon }\end{array}$ & $\begin{array}{l}\text { Az önfenntartás ke- } \\
\text { reteinek erősítése a } \\
\text { lokális gazdaság } \\
\text { fejlesztésével }\end{array}$ & $\begin{array}{l}\text { Gazdasági fenntart- } \\
\text { hatóság, piaci ered- } \\
\text { ményesség, jövedelem- } \\
\text { termelő képesség }\end{array}$ \\
\hline $\begin{array}{l}\text { A meghatározó } \\
\text { szervezeti keret }\end{array}$ & $\begin{array}{l}\text { Nem piaci szervezetek } \\
\text { (harmadik szektor) }\end{array}$ & $\begin{array}{l}\text { Nem piaci és piaci } \\
\text { szervezetek határán lévő } \\
\text { "félpiaci szervezetek" } \\
\text { (pl. szövetkezetek) }\end{array}$ & $\begin{array}{l}\text { Piaci szervezetek } \\
\text { beemelése a nem piaci } \\
\text { szervezetek mellé }\end{array}$ \\
\hline $\begin{array}{l}\text { A domináns megjelenés } \\
\text { forma }\end{array}$ & $\begin{array}{l}\text { i Nonprofit szervezetek, } \\
\text { egyesületek, } \\
\text { alapítványok }\end{array}$ & $\begin{array}{l}\text { Szövetkezetek, szociális } \\
\text { szövetkezetek }\end{array}$ & Társadalmi vállalkozáso \\
\hline A müködés fö forrásai & $\begin{array}{l}\text { A nonprofit szervezetek } \\
\text { állami és közösségi } \\
\text { támogatása, hogy a } \\
\text { közösségi védelmi } \\
\text { funkciót elláthassák }\end{array}$ & $\begin{array}{l}\text { (Időben, pénzben) } \\
\text { korlátozott (állami, } \\
\text { közösségi) támogatás és } \\
\text { saját gazdasági ered- } \\
\text { mény }\end{array}$ & $\begin{array}{l}\text { Gazdasági eredmények } \\
\text { elsődlegessége és az } \\
\text { állami és közösségi } \\
\text { támogatási formák } \\
\text { kiegészítő jellege }\end{array}$ \\
\hline $\begin{array}{l}\text { Kapitalizmushoz való } \\
\text { viszony }\end{array}$ & Korrektív & Kiegészítő & $\begin{array}{l}\text { Befogadó (pl. tel- } \\
\text { jesítményelvű értékelés } \\
\text { rendszerek, befektetési } \\
\text { szemlélet érvényesülés }\end{array}$ \\
\hline Célcsoport & $\begin{array}{l}\text { Munkanélküliek, } \\
\text { munkaerőpiaci szem- } \\
\text { pontból hátrányos } \\
\text { helyzetű személyek }\end{array}$ & $\begin{array}{l}\text { Peremhelyzetű tár- } \\
\text { sadalmi csoportok }\end{array}$ & $\begin{array}{l}\text { Egyéni és közösségi } \\
\text { vállalkozások (munka- } \\
\text { nélküli és perem- } \\
\text { helyzetű személyek } \\
\text { bevonásával) }\end{array}$ \\
\hline Szociálpolitikai háttér & $\begin{array}{l}\text { Szociális jogok garantá- } \\
\text { lása, társadalmi felelős- } \\
\text { ségvállalás }\end{array}$ & $\begin{array}{l}\text { Feltételekhez (többnyire } \\
\text { munkához) kötött jóléti } \\
\text { ellátás, } \\
\text { “nincs jog kö- } \\
\text { telezettségek nélkül” }\end{array}$ & $\begin{array}{l}\text { Szociális beruházás } \\
\text { elmélet, befektető jóléti } \\
\text { állam }\end{array}$ \\
\hline
\end{tabular}


juk fokának szempontjából vizsgálják, eredményességüket piaci mércével, a piaci tevékenységeik nagyságában bekövetkező növekedéssel (gazdasági fenntarthatóság, eredményesség, profit?) mérik. Ez is azt erősíti, hogy müködésében napjainkban egyre határozottabb szerepet kap a gazdasági elem a társadalmival szemben.

A szociális gazdaság alappillére az elmúlt 30 év változásainak következményeként így mindkét esetben - bár ellenkező előjelű mozgásiránynak köszönhetően - megingott. Az európai országok többségében a harmadik szektor és a piac, míg Magyarország esetében a harmadik szektor és az állam között tűnnek el a jól azonosítható határok.

A piaci és társadalmi érdekek kibékítésére irányuló törekvés a harmadik szektor létrehozásával, a szociális gazdaság megerősítésével, úgy tűnik, nem vezetett eredményre. Sőt, a szociális gazdaság ebben a napjainkra átalakult formájában sok esetben a fennálló, piaci érdekeket képviselő rendszerek stabilizációjához járul hozzá.

\section{Szociális és szolidáris gazdaság (SSG)}

A szociális gazdaság szervezeteit az elmúlt 30 évben a legtöbb esetben ott müködtették, ahol az első két szektor kudarcot vallott. Mint harmadik, kiegészítő szektor a szervezők szándéka szerint a gazdaság müködésének egy alternatív modelljét (etikus, szolidáris, nonprofit gazdaság) képviselte, de az alapproblémát, a profitelvű formális gazdaság társadalmi egyenlőtlenséget növelő működési rendjét nem kérdőjelezte meg. Így hiába töltött be a helyi gazdaságban és a peremhelyzetű csoportok foglalkoztatásban akár figyelemre méltó szerepet, valós politikai súlyra nem sikerült szert tennie, s így a probléma keletkezésének megelőzésében nem, csupán korrekciójában vehetett részt (Laville 2018).

A szolidáris gazdaság koncepció a szociális gazdasághoz képest határozottabb politikai szerepválallást, illetve a gazdaság és társadalom teljes átalakítását tűzi ki célul. A szolidáris gazdaságot a kapitalista fejlődés alternatívájának, egy lehetséges új fejlődési modellnek tekintik (Neamtan 2002).

A szolidáris gazdaság koncepciója az ezredforduló körül a baloldali, délamerikai, vagy ázsiai fejlődő országokban erősödött meg (Monzón, Chaves 2008). Célszerü azonban megemlíteni, hogy a szolidáris gazdaság fogalom kialakulásának és elterjedésének európai bázisa is van: Franciaország15 (Laville 2010; Guérin 2014; Defourney 2014).

A szolidáris gazdaság fogalma nem új keletű, hiszen Polányi már a múlt század közepén bemutatott egy, a ma domináns piaci elvekkel szemben definiált plurális gazdaság szemléletmódot, amelyben a piac és a redisztribució mellett a reciprocitásnak is központi szerepe van (Polányi 1944). Polányira alapozva Miller úgy véli, a szolidáris gazdaság meghatározásakor „az összes olyan különféle módszer [figyelembe veendő], melyek révén az emberi közösségek kielégíthetik szükségleteiket és közösen biztosíthatják megélhetésüket” (Miller 2018, 89.). 
McMurtry (2018) szerint amint a kapitalista rendszer uralkodni kezdett a korai vagy vegyes gazdasági rendszerek felett, törvényszerüvé és szükségessé vált a vele szemben álló alternatívák megfogalmazása. Az egyik ilyen alternatíva a több gazdasági integrációs modellt is magába olvasztó szolidáris gazdaság, melyet Polányi (1944) szubsztantív vagy beágyazott gazdasági modellként jellemzett a kapitalista árutermelö, profitorientált piacgazdasággal szemben (Csoba 2007).

A szolidáris modell jól illeszkedik a napjainkban egyre gyorsabb ütemben jelentkező gazdasági válságok, a társadalmi egyenlőtlenségek, valamint a klímakatasztrófa fenyegetéseinek csökkentését irányzó baloldali modellek sorába, mivel egy demokratikus, gazdasági és ökológiai szemponból is fenntartható társadalomirányítási forma megteremtését tűzi ki célul. Képviselőik a „nem-kapitalista jövő" jelszavai mentén a társadalmi együttélés és a gazdaság müködtetésének szolidáris megoldásait keresik.

A szolidáris és szociális gazdaság több meghatározó ponton is különbözik egymástól (2. táblázat): míg a szolidáris gazdaság kifejezetten szisztematikus, átalakító, posztkapitalista programmal rendelkezik, a szociális gazdaság a kapitalizmusba illeszkedik. A szociális gazdaság helyi gazdaságfejlesztésre fókuszáló modelljével szemben a szolidáris gazdaság nemzeti és globális szintű koordinációra is képes mozgalom, és gazdasági formációk támogatását állítja fókuszba. A szolidáris gazdaság lényegéből adódóan nem korlátozódik a harmadik szektorban megvalósuló tevékenységekre, müködése során mindhárom szektort átható gazdasági modell megvalósítására törekszik (Miller 2007).

A két modell a célcsoportjában is különbözik egymástól. A szociális gazdaság (talán a társadalmi vállalkozás bizonyos szegmenseit kivéve) a legtöbb esetben a munkanélküliek, peremhelyzetű társadalmi csoportok integrációját, társadalmi beillesztését segítő lokális gazdaság fejlesztését állítja középpontba, a szolidáris gazdaság nemcsak a szegények integrációját, hanem a társadalom valamennyi tagjának bevonását célozza.

A 2000-es évek elején a szolidáris gazdaság legkülönfélébb (zöld, antikapitalista, ökológiai, közösségi) modelljét képviselő mozgalmak és nemzetközi hálózatok jöttek létre (pl. RIPESS), és erősítették a szolidáris gazdaság fogalom megjelenését az észak-amerikai és európai szakmai vitákban, gyakorlati projektekben és a szervezetek működését lehetővé tevő jogszabályi környezet formálásában.

A szolidáris gazdaság fogalom tartalmának „többrétegűsége” azonban komoly akadályt jelent a szakirodalomban való tájékozódás során. Csak alapos elemzést követően tudjuk eldönteni, hogy:

- a szerző a szolidáris gazdaságot a szociális gazdaság szinonímájaként használja, mint a legtöbb európai országban;

- a szolidáris gazdaság kifejezés használatakor a szociális gazdaság fogalomhoz képest lényegesen több politikai elemet jelenít meg, de a keretfeltételeket (kapitalista gazdaság) nem kérdőjelezi meg (Laville 2010). Az 
2. táblázat: A szociális gazdaság és a szolidáris gazdaság karaktervonásai Characteristics of social economy and solidarity economy

\begin{tabular}{|c|c|c|}
\hline \multicolumn{3}{|c|}{ ics of social economy and so } \\
\hline & Szociális gazdaság & Szoli \\
\hline Regionális meghatározottság & Európai régió & $\begin{array}{l}\text { Latin-amerikai, ázsiai országok, } \\
\text { Franciaország }\end{array}$ \\
\hline Ideológiai alapok & $\begin{array}{l}\text { A kapitalizmussal és a szocializ- } \\
\text { mussal szemben egy }\end{array}$ & $\begin{array}{l}\text { A kapitalizmust és a neoliberális } \\
\text { ideológiát egyértelműen elvető }\end{array}$ \\
\hline & $\begin{array}{l}\text { "megreformált "szociáldemokra- } \\
\text { ta értékrendszer, "harmadik út" } \\
\text { (Giddens 1998) }\end{array}$ & baloldali értékrendszer \\
\hline A kapitalizmushoz való viszony & A kapitalizmus elfogadása & A kapitalizmus tagadása \\
\hline Működési terület & $\begin{array}{l}\text { Az állam és a piac mellett } \\
\text { kiegészítő jelleggel a harmadik } \\
\text { "nonprofit" szektor kereteiben } \\
\text { működik }\end{array}$ & $\begin{array}{l}\text { Valamennyi szektort átfogó, és } \\
\text { nem kiegészítő, vagy korrektív } \\
\text { működési mód }\end{array}$ \\
\hline Elsődleges cél & $\begin{array}{l}\text { A peremhelyzetű csoportok } \\
\text { integrációja, a társadalmi kohé- } \\
\text { zió növelése }\end{array}$ & $\begin{array}{l}\text { A gazdaság és a társadalom jelen } \\
\text { legi müködési rendjének megvál } \\
\text { toztatása (pl. ökológiai, elosztási } \\
\text { problémák kezelése), formális } \\
\text { gazdaság helyett “beágyazott } \\
\text { gazdaság” létrehozása (Polányi } \\
\text { 1944) }\end{array}$ \\
\hline Hatókör & $\begin{array}{l}\text { Lokális gazdaság és társadalom } \\
\text { fejlesztése } \\
\text { "Acting Locally for Employment } \\
\text { (Evers, Laville 2004, 199.)" }\end{array}$ & $\begin{array}{l}\text { Globális mozgalmak, hálózatok } \\
\text { szervezése a lokális cselkvési tér } \\
\text { fejlesztése mellett }\end{array}$ \\
\hline Kiemelt cselekvési területek & $\begin{array}{l}\text { Foglalkoztatási és gazdasági } \\
\text { dimenzió }\end{array}$ & $\begin{array}{l}\text { Gazdasági, szociális, } \\
\text { esélyegyenlőségi (pl. gender) és } \\
\text { ökológiai kérdések beemelése }\end{array}$ \\
\hline Célcsoport & $\begin{array}{l}\text { Az első és második szektorból } \\
\text { kiszoruló személyek }\end{array}$ & A társadalom valamennyi tagja \\
\hline
\end{tabular}

Forrás: Saját szerkesztés

ezredfordulót követően a szakmai és politikai szervezetek (EC, OECD, ILO) dokumentumainak jó részében ezzel a fogalomértelmezéssel találkozunk;

- a szolidáris gazdaság fogalmát mint a gazdaság müködésének új (antikapitalista) értelmezési keretét használja (Kawano 2013).

A fogalmi keretek meghatározásakor további nehézséget jelent, hogy a szolidáris gazdaságot mozgalomként vagy szervezeti, működési formaként értelmezzük-e. A 2002-ben megalakult Szociális és Szolidáris Gazdaság Világszervezete, a RIPESS ${ }^{16}$ szerint a ,társadalmi és szolidáris gazdaság egy mozgalom, mely meg kívánja reformálni az uralkodó társadalmi és gazdasági rendszert" (RIPESS 2015, 10.).

Más vélemények - például a 2019-ben Magyarországon létrehozott Szolidáris Gazdaság Központ ${ }^{17}$ deklarációja - szerint a „szolidáris gazdaság nem csupán 
egy mozgalom, hanem egy szervezeti, müködési forma is, melynek keretében a társadalmi igazságosság és az ökológiai fenntarthatóság elveinek megfelelően szervezik meg az alapvető emberi igények kielégítését, kiszakítva azokat a tőkefelhalmozás folyamataiból, helyi, nem árutermelő gazdálkodókért küzdenek a nagy területigényü, exportorientált kapitalista agráripari vállalatokkal szemben" (Szolidáris Gazdaság Központ 2020).

Ennek értelmében beszélhetünk a szolidáris gazdaság keretében közösségi ház- és kertprojektekről, fogyasztói-termelői közösségekről, helyi cserekereskedelmi rendszerekről, adományboltokról, nyílt forrású projektekről, háztartási és ápolási feladatok körül szerveződő közösségekről, bérlői lakásszövetkezetekről, zöldenergia-közösségekről és más termelői, szolgáltatói és a reciprocitást előtérbe helyező támogatói csoportokról és kapcsolódó kezdeményezésekről, anélkül, hogy a szereplőket és a szervezeti kereteket pontosan definiálnánk (Miller 2007; Szolidáris Gazdaság Központ 2020).

A szolidáris gazdaság első szervezetei és képviselői - mint például a fent említett Szolidáris Gazdaság Központ, vagy a SUSY hálózat ${ }^{18}$ - a közelmúltban Magyarországon is megjelentek.

Mára a demokratikus és fenntartható gazdasági formákkal foglalkozó nemzetközi kutatóhálózatok a „szociális és szolidáris gazdaság” (Social and Solidarity Economy, SSE) átfogó megnevezést használják, különbséget téve a különböző létező gazdasági formákra utaló „,ársadalmi vállalkozás”, „,szövetkezeti” vagy „,szociális gazdaság", és a rendszerszintű átalakítás programját is magába foglaló „szolidáris gazdaság” kifejezései között.

A „szociális és szolidáris gazdaság” (SSG) fogalom használata azonban nem problémamentes, hiszen a szociális és a szolidáris gazdaságnak - mint a fentiekből is kitűnt - alapvetően különböző céljai vannak, s más ideológiai háttérrel rendelkeznek.

A szociális gazdaság elemzésekor jeleztük, hogy az elmúlt 30 év bármelyik korszakát is vizsgáljuk, meg kell állapítanunk, hogy „minden formája liberális elméleteken nyugszik" (McMurtry 2018, 65.), cselekvési terét a kapitalista gazdaság keretein belül határozza meg. Ezzel szemben a szolidáris gazdaság a kapitalizmussal szembeni alternatívaként definiálja magát, akár mozgalomról, akár szervezeti vagy működési formáról van szó. A két fogalom együttes használata egyfelől elfedi a szociális és szolidáris gazdaság fogalmak valódi tartalmát, másfelől olyan mítoszokhoz és társadalmi csapdákhoz vezet, amelyek akadályozzák a gazdasági, társadalmi és ökölógiai problémák megoldását. A jóléti állam felelősségvállalásának csökkentésével például mind erőteljesebben csökken az állampolgárok szociális jogainak intézményesített védelme, s helyette a harmadik szektor szervezetei, közösségei válnak kulcsszereplővé az emberek jóléte és a környezet minőségének védelme során. A szociális gazdaság értelmezése szerint a kapitalizmus keretei között születnek meg a problémát kezelő „közösségi” megoldások, miközben a problémát kiváltó keretfeltételek változatlanok maradnak. A 
szociális és szolidáris gazdaság fogalma ilyen értelemben akár „trójai faló” (McMurtry 2018) is lehet, amely jól szolgálja azt a neoliberális értékrendet, amelyet a harmadik szektor épp, hogy megkérdőjelezni szándékozott.

\section{Összegzés}

A szociális gazdaság az elmúlt 30 év során a környezeti feltételek hatására folyamatosan változó fókusszal (pl. nonprofit vállalkozás, szövetkezet, társadalmi vállalkozás), de többnyire a kapitalista modell szerint szerveződő gazdasági formációkban fejlődött Európában. A kilencvenes években még a foglalkoztatási lehetőségek bővítését és a jóléti állam szociális biztonságban játszott szerepét hangsúlyozó szociális gazdaság napjainkra az állampolgárok felelősségére építő és a társadalmi vállalkozások önfenntartó szerepét hangsúlyozó modellé változott. ${ }^{19}$ Megerősödött a teljesítményelvekre épülő, a társadalmi integráció helyett a gazdasági fenntarthatóságot előtérbe helyező eleme, illetve alárendelődött az első két szektor működésének (lásd jogi, működési keretek állami szabályozása, finanszírozási formák). A „kétpólusú” átalakulás eredményeként a nyugati országokban a piaci, Magyarországon az állami szektor áramlott be a várakozásokhoz képest egyre kisebb hatásfokkal működő harmadik szektor területére.

Az átalakulás hátterében jól azonosítható a 20. század utolsó évtizedének és a 21. század első két évtizedének folyamatosan változó gazdasági, politikai/ideológiai és társadalmi környezete, amelyben a liberális piacgazdaság és a válságban lévő jóléti állam kiútkeresési kísérletei zajlottak. Ezt tükrözik a mérvadó nemzetközi szervezetek, ezen belül is kiemelten az Európai Unió programadó dokumentumai. Az európai uniós normák átvétele és a Strukturális Alapok támogatása - mint a magyarországi példa is mutatja - adhat ösztönzést a szektor fejlesztéséhez, ugyanakkor az érintett területek eltérő ütemű fejlődése, vagy az olyan ,polgári értékek, mint az önállóság, a felelősség, a függetlenség, a saját sorsán változtatni akaró és képes egyének és közösségek" (G. Fekete 2018, 113.) hiánya látszatmegoldásokhoz vezethet, és gátolhatja a társadalmi kezdeményezések kialakulását.

A harmadik szektor átalakulásával párhuzamosan az ezredfordulót követően fokozatosan teret hódított a szolidáris gazdaság modell, amely a szociális gazdaság klasszikus területei (foglalkoztatási, helyi gazdaságfejlesztés, közösségi vállalkozás) mellett a 21. század új kockázati területeit (ökológiai, kulturális, esélyegyenlőségi, gender) is beemelte a fogalomba, s mindemellett vállaltan antikapitalista célokat tüzött ki.

A demokratikus és fenntartható gazdasági formákkal foglalkozó nemzetközi kutatóhálózatok a „szociális és szolidáris gazdaság”(SSG) fogalom bevezetésével kívánták kifejezni a szociális gazdaság szervezeti, működési formára (pl. nonprofit szervezet, szövetkezet, társadalmi vállalkozás) fókuszáló és a rendszerszintű 
átalakítás programját is magába foglaló „szolidáris gazdaság” fogalmak közötti különbséget. A „szociális és szolidáris gazdaság” (SSG) fogalom használata azonban továbbra sem problémamentes, hiszen az így létrehozott kifejezés (SSG) elfedi a szociális és a szolidáris gazdaság közötti alapvető értékkülönbséget, s lehetőséget biztosít a fogalmak saját érdekek szerinti tartalommal való feltöltésére, illetve ennek következtében a modellekkel való visszaélésre.

A Szociális gazdaság kézikönyv (Frey et al. 2007) készítésekor az volt a célunk, hogy rövid áttekintést adjunk az EU fejlesztési programjaiban kiemelt szerepet betöltő szociális gazdaság elméletéről és gyakorlatáról a fogalommal akkor ismerkedő hazai szakmeberek számára. Tizenöt év után a „szociális és szolidáris gazdaság" (SSG) értelmezése állít bennünket újabb feladat elé. Nem gondoljuk, hogy ma egyszerübb lenne eligazodni az érdekek, értékek, modellek és fogalmak dzsungelében, mint az előző alkalommal. Annak ellenére sem, hogy G. Fekete Éva és kutatóműhelyének eredményei, a Kézikönyv megjelenése óta publikált írásai még hosszú időre biztos fogódzót jelentenek mind a gyakorlati szakemberek, mind a szociális és szolidáris gazdaság összefüggéseinek feltárására vállalkozó kutatók számára.

Tanulmányunk készítésével nem az volt a célunk, hogy Éva szavait kölcsönözve azt igazoljuk, „... a szociális gazdaság koncepció dugába dől, mielőtt megszületne." 20 Polányi gazdasági integrációs sémákkal kapcsolatos alapfeltevését elfogadva úgy véljük, hogy a ma meghatározó árutermelő és piacgazdaság nem az egyedüli lehetséges modell, $\mathrm{s}$ a plurális gazdasági szemléletmód lehet a 21. század hatékony stratégiája, amelyben mindenképpen helye van a szolidáris (beágyazott) gazdaságnak is (Polányi 1944). A szociális gazdaság változásának és karaktervonásainak talán helyenként sarkított elemzésével csupán arra kívántuk felhívni a figyelmet, hogy egy fogalom belső tartalmának átalakulása ${ }^{21}$ a legjobb szándék mellett is könnyen tévútra vezethet.

\section{Jegyzet}

1 A tanulmány terjedelmi korlátai csak a legfontosabb trendek elemzését teszik lehetővé. Az Európai Unió régiói és jóléti modelljei közötti eltéréseket, egyedi utakat - jóllehet azok jelentőségét nem vitatjuk - nem áll módunkban részletesen vizsgálni.

2 Franciaországban az 1970-es években létrejött Önsegélyező, Szövetkezeti és Szövetségi Tevékenységek Nemzeti Összekötő Bizottsága (CNLAMCA) 1980 júniusában kiadott egy dokumentumot, a "Charte de 1 'économie sociale-t" (a szociális gazdaság chartáját), amelyben a szociális gazdaságot olyan szervezetek összességeként határozza meg, amelyek nem tartoznak az állami szektorhoz, egyenlő jogokkal és kötelességekkel rendelkező tagokkal, demokratikusan mủködnek, és a nyereséget a szervezet bővítésére és a tagoknak, illetve a társadalomnak nyújtott szolgáltatások fejlesztésére fordítják (Nirello, Prouteau 2018). A szociális gazdaság kifejezést azonban már jóval korábban, a 19. században is használták (lásd OECD 2003,298.).

3 További részletek a szociális gazdaság hivatalos honlapján: https://ec.europa.eu/growth/sectors/so_ cial-economy_en 
Erről lásd még az 1997-ben alakult Foglalkoztatási Célú Nonprofit Szervezetek Szövetsége honlapját, vagy a következő linket: http://www.focenosz.hu/magunkrol

5 A helyi gazdaságfejlesztés fogalmát jelen esetben Mezei (2006) definicíója alapján használjuk, amely szerint ide tartozik minden olyan, a helyi gazdaság fejlesztésére irányuló tudatos beavatkozás, ahol a helyi szereplők kezdeményezőként, támogatóként, megvalósítóként aktívan részt vesznek a fejlesztési folyamatban. E tekintetben a helyi gazdaság fejlesztése a lokális foglalkoztatás bővítésénél szélesebben értelmezendo”.

http://szoszov.hu/ensz-hatarozat-a-szovetkezetek-szereprol

7 A „Szövetkezetek a Vállalkozóbarát Európában” című dokumentum az Európai Unió Bizottság munkadokumentuma. A 2002. október 10-11-i lisszaboni konferencián mutatták be.

Magyarul megjelent a Szövetkezés, 2002/1-2., 182-219..

9 http://szoszov.hu/ilo-ajanlas-a-szovetkezetek-tamogatasarol

10 A szociális szövetkezeti modell gyors ütemű és széleskörű fejlődése az EU-ból érkező támogatásoknak volt köszönhető.

11 2007-ben egy, 2015-ben már 2490 szociális szövetkezetet tartottak nyilván (Havas, Molnár 2017).

12 „Szociális vállalkozások felhatalmazása az innovációra, befogadó növekedésre és munkahelyteremtésre" című, 2014. január 16-17-én Strasbourgban tartott konferencia záródokumentuma. http:// szoszov.hu/a-strasbourgi-nyilatkozat-2014-a-szocialis-vallalkozasok-hozzajarulasa-europahoz

13 Az OFA számára kiírt GINOP-5.1.2 számú, „Társadalmi vállalkozások ösztönzése - kiemelt projekt" címü felhívásban olvasható.

14 A 2016. évi CVLV. törvény 15. § 41 (1) - 42 szakasza szerint a szociális szövetkezetnek a természetes személy tagjain kívül legalább egy helyi önkormányzat vagy nemzetiségi önkormányzat, illetve ezek jogi személyiségủ társulása vagy jogszabályban meghatározott karitatív tevékenységet ellátó közhasznú jogállású szervezete is kötelező tagja.

15 Ha a szolidáris gazdaság fogalma európai viszonylatban merül fel, annak tartalma a legtöbb esetben sokkal közelebb áll a szociális gazdaság fogalom tartalmához (piacgazdaság keretei között, de nonprofit alapon működő társadalmi vállalkozások), mint a szociális gazdaság latinamerikai és ázsiai régióban való értelmezéséhez (antikapitalista értelmezési keret). Európában a köznyelv többnyire nem tesz különbséget a kettő között, és szakértői, szakpolitikai dokumentumokban is gyakran szinonímaként használják a két fogalmat.

16 A témára vonatkozó további információk megtalálhatók a szervezet honlapján http:// www.ripess.org/?lang=en http://www.ripess.org/wp-content/uploads/2017/08/RIPESS_VisionGlobal_EN.pdf

17 A Szolidáris Gazdaság Központ honlapján a szervezet küldetéséről és tevékenységéről további részletek olvashatók: https://szolidarisgazdasagkozpont.hu

18 A 2015-2018 között múködött SUSY hálózatról, illetve a magyarországi jó gyakorlatokról további információ elérhető az alábbi linkeken: http://hu.solidarityeconomy.eu/what/; http:// hu.solidarityeconomy.eu/fileadmin/Media/hu.solidarityeconomy.eu/SUSY_bestpractice.pdf

19 A foglalkoztatás szerepe azonban továbbra is kulcsfontosságú maradt, hiszen a társadalmi vállalkozások elsősorban e szerephez kapcsolódva kapnak uniós finanszírozást.

20 A konferencia összefoglalója, ahol a megfogalmazás elhangzott: https://reszvetelidemokracia.blog.hu/ 2007/09/28/vas_es_acel_orszaga_vagy_tudastarsadalom

21 Lásd például G. Fekete Évának a közfoglalkoztatásról (G. Fekete 2015), vagy a Lipták Katalinnal a szociális szövetkezetekről (G. Fekete, Lipták 2014) szóló írásait. 


\section{Irodalom}

Borzaga, C., Galera, G., Nogales, R. (2008): Social enterprise: A new model for poverty reduction and employment generation. United Nations Development Programme and EMES, https://www.undp.org/content/undp/ en/home/librarypage/poverty-reduction inclusive_developmentsocial_enterpriseanewmodel forpovertyreductionandemploymentgenera.html (Letöltés: 2020.06.18.)

Borzaga, C., Depedri, S. (2013): When social enterprises do it better. In: Denny, S., Seddon, F. (eds.): Social enterprise: Accountability and evaluation around the world. Routledge, New York, 85-102.

Borzaga, C., Salvatori, G., Bodini, R. (2017): Social and solidarity economy and the future of work. International Labour Organization, Geneva, 1-49. https://www.ilo.org/wcmsp5/groups/public/---ed_emp/--emp_ent/---coop/documents/publication/wcms_573160.pdf (Letöltés: 2020.06.18.)

Campbell, M. (2000): The Third System, Jobs and Local Development: European Experience. Conference paper presented to the ISTSR International Conference on the Third Sector, Dublin, Ireland 4-7 July 2000. https://cdn.ymaws.com/www.istr.org/resource/resmgr/working_papers_dublin/ campbell.pdf (Letöltés: 2020.07.02.)

Castel, R. (1998): A szociális kérdés alakváltozásai. Max Weber Alapítvány, Wesley Zsuzsanna Alapítvány, Kávé Kiadó, Budapest

Ciepielewska-Kowalik, A., Pielinski, B., Starnawska, M. (2015): Social Enterprise in Poland. Institutional and Historical Context. ICSEM Working Papers (No. 11) https://citeseerx.ist.psu.edu/viewdoc/ download?doi=10.1.1.1048.3381\&rep=rep1\&type=pdf (Letöltés: 2020.06 .18 .)

CIRIEC (2012): A szociális gazdaság az Európai Unióban - CIRIEC (A Köztulajdonú, Szociális és Szövetkezeti Gazdaság Nemzetközi Kutató- és Tájékoztatóközpontja) által az Európai Gazdasági és Szociális Bizottság részére készített jelentés összefoglalása. http://www.eesc.europa.eu/resources/docs/ a_ces11042-2012_00_00_tra_etu_hu.pdf (Letöltés: 2020.06.15.)

Conill, J., Castells, M., Cardenas, A., Lisa, S. (2012): Beyond the crisis: The emergence of alternative economic practices. In: Castells, M., Caraca, J., Cardoso, G. (eds.): Aftermath:The cultures of the economic crisis. Oxford University Press, London, 210-250.

Conscise Project (2000): The contribution of social capital in the social economy to local economic development in Western Europe. Report of Work package 1: Key concepts, measures and indicators. Middlesex University, http://www.conscise.mdx.ac.uk (Letöltés: 2020.06.25.)

Coraggio, J., Eynaud, P., Ferrarini, A., De Franca Filho, G. C., Gaiger, L. I., Laville, J. L., Lemaitre, A., Sadik, Y., Veronese, M., Wanderley, F. (2015): The theory of social enterprise and pluralism: Solidarity-type social enterprise. In: Laville, J. L., Young, D. R., Eynaud, P. (eds.): Civil society, the third sector and social enterprise. Routledge, London, 234-250.

Csoba J. (2007): A szociális gazdaságot életre hívó folyamatok. In Frey M.: (szerk.): Szociális gazdaság kézikönyv. OFA, Budapest, 7-19.

Csoba J. (2015): A jóléti rendszer átalakulásának hatása a helyi önkormányzatok szerepének változására. Metszetek - Társadalomtudományi folyóirat, 4., 54-68. https://doi.org/10.18392/metsz/ $2015 / 4 / 3$

Csoba J. (2017): Gondoskodó állam, aktiváló állam, befektető állam: A foglalkoztatáspolitika és a jóléti modellváltás néhány összefüggése. socio.hu Társadalomtudományi Szemle, 1., 1-26. https:// doi.org/10.18030/socio.hu.2017.1.1

Defourny, J. (2001): From Third Sector to Social Enterprise. In: Borzaga, C., Defourny, J. (eds.): The Emergence of Social Enterprise. Routledge, London and New York, 1-28.

Defourny, J. (2014): From third sector to social enterprise: A European research trajectory. In: Defourny, J., Hulgård, L., Pesto, V. A. (eds.): Social Enterprise and the Third Sector. Changing European Landscapes in a Comparative Perspective. Routledge, London, 17-41.

Defourny, J., Nyssens, M. (2014): The EMES approach of social enterprise in comparative perspective. In: Defourny, J., Hulgård, L., Pestoff, V. (eds.): Social enterprise and the third sector: Changing European landscape in a comparative perspective. Routledge, London, 42-65.

Defourny, J., Nyssens, M. (2016): Fundamentals for an International Typology of Social Enterprise Models. ICSEM Working Papers, No. 33, Liege: The International Comparative Social Enterprise Models 
(ICSEM) Project.http://www.iap-socent.be/sites/default/files Typology\%20\%20Defourny\%20 \%26\%20Nyssens.pdf (Letöltés: 2020.10.15.)

Depedri, S. (2010): The competitive advantages of social enterprises. In: Becchetti, L., Borzaga, C. (eds.): The economics of social responsibility. Rotledge, New York, 34-54.

Dohnalová, M., Guri, D., Hrabětová, J., Lagnerová, K., Šlechtová, V. (2016): Social Enterprise in the Czech Republic. In: ICSEM Working Papers No. 24. https://www.iap-socent.be/sites/default/ files/Czech\%20Republic\%20-\%20Dohnalova\%20et\%20al_0.pdf (Letöltés: 2020.06.18.)

EC (1995): European Strategy for encouraging local development and employment initiatives. COM (95) 273 final. EC Brussels http://aei.pitt.edu/2785/ (Letöltés: 2020.06.20.)

EC (1993): Growth, Competitiveness, Employment, Challenges and Ways forward into the 21st Century. White Paper, ECSC-EC-EAEC, Brussels-Luxembourg http://aei.pitt.edu/1139/ (Letöltés: 2020.06.20.)

EC (2011a): Communication from the Comission to the European Parlament, the Council, Economis and Social Committee and the Committee of Regions. Review of the "Small Business Act" for Europe. COM(2011) 78 final. EC Brussels https://eur-lex.europa.eu/legal-content/EN/TXT/PDF/?uri=CELEX:52011DC0078\&from=EN (Letöltés: 2020.06.20.)

EC (1997): Proposals of Employment Guidelines for MemberState Employment Policies for 1998. COM(497) EC Brussels http://aei.pitt.edu/3503/ (Letöltés: 2020.06.20.)

EC (2011b): Social Business Initiative, Communication from the Commissiontothe European Parliament, the Council, the European Economic and Social Committee and the Committee of the Regions. $\operatorname{COM}(2011)$ 682 final. EC Brussels https://ec.europa.eu/transparency/regdoc/rep/1/2011/EN/1-2011682-EN-F1-1.Pdf (Letöltés: 2020.06.20.)

EC (2013): Social economy and social entrepreneurship. Social Europe guide.Vol. 4. Brussels, DirectorateGeneral for Employment, Social Affairs and Inclusion, 1-112. https://sofisam.se/download/ 18.3453fc5214836a9a472a0430/1472023483855/EU+kommissionen,+Social+Economy+and+Social+ Entreprenreurship.pdf] (Letöltés: 2020.06.28.)

EC (2015): A map of social enterprises and their eco-systems in Europe. Directorate-General for Employment, Social Affairs and Inclusion, EC Brussels https://www.google.com/url?sa=t\&rct=j\&q=\&esrc= s\&source=web\&cd=\&cad=rja\&uact $=8 \& v e d=2$ ahUKEwihsbLhg-TsAhXnyYUKHeI_ChsQFjAAeg QIAxAC\&url=https\%3A\%2F\%2Fec.europa.eu\%2Fsocial\%2FBlobServlet\%3FdocId\%3D12987\%26la ngId\%3Den\&usg=AOvVaw0zDCAohUz7bdCbHUz6nXN9 (Letöltés: 2020.06.20.)

EC (2020): Social enterproses and their ecosystems in Europe. Comparative synthesis report. Publications Office of the European Union, Luxemburg https://op.europa.eu/en/publication-detail/-/publication/ 4985a489-73ed-11ea-a07e-01aa75ed71a1/language-en (Letöltés: 2020.10.15.)

Egyesült Nemzetek Szervezete 56. Közgyűlése 88. Plenáris Ülésének határozata a szövetkezetek szerepe a társadalmi fejlődésben (2001. dec. 19.) http://misc.meh.hu/binary/5537_ensz56k_zgy_jav.doc (Letöltés: 2020.06.28.)

Európai Bizottság (2019): Társadalmi vállalkozások és ökoszisztémáik Európában. Magyar országjelentés. Szerzők: Kiss J. és Mihály M. Fordította: Kiss J. http://unipub.lib.uni-corvinus.hu/4246 (Letöltés: 2020.07.05.)

Evers, A., Laville, J.L. (2004): The Third Sector in Europe. Edward Elgar Publishing Cheltenham UK, Northampton MA USA

Ferge Zs. (1991): Szociálpolitika és társadalom. ELTE Szociológia Intézet Szociálpolitika Tanszéke, T-Twins Kiadói és Tipográfiai Kft., Budapest

Fonteneau, B., Neamtan, N., Wanyama, F., Morais, L. P., Poorter, M., Borzaga, C., Galera, G., Fox, T., Ojong, N. (2011): Social and Solidarity Economy: Our common road towards Decent Work. International Training Centre of the International Labour Organization, Geneva https:// ilo.org/wcmsp5/groups/public/---ed_emp/---emp_ent/---coop/documents/instructionalmaterial/ wcms_166301.pdf (Letöltés: 2020.06.22.)

Frey M. (1997): Nonprofit szervezetek helyi foglalkoztatási kezdeményezései. Vezetéstudomány, 5., 43-55.

Frey M. (1999): Munkahelyteremtés a munkaerőpiac fó áramlatán kívül. Munkaügyi Szemle, 5., 25-28.

Frey M. (2001): Nonprofit szervezetek a munkaerőpiacon. Országos Foglalkoztatási Közalapítvány Munkaügyi Kutatások Szakmai Műhelye, Budapest 
Frey M., G. Fekete É., Csoba J., Lévai M., Soltész A. (2007): Szociális gazdaság kéziköny. OFA, Budapest

Foucault, M. (1998 [1971]): A diskurzus rendje. In: Foucault, M.: A fantasztikus könyvtár. Válogatta és fordította Romhányi Török G. Pallas Stúdió, Attraktor Kft., Budapest, 50-74.

Futó P. (szerk.) (2004): A szociális gazdaság jelene és jövője Magyarországon, a szektor civil szervezetei és azok képzési igényei. SEED Kisvállalkozás-fejlesztési Alapítvány, Budapest

Futó P., Hanthy K., Lányi P., Mihály A., Dr. Soltész A. (2005): A szociális gazdaság jelene és jövője Magyarországon. Kutatási zárótanulmány. Nemzeti Felnőttképzési Intézet, Budapest

G. Fekete É. (1990): Élni a Csereháton?! Csereháti Településszövetség, Gagyvendégi

G. Fekete É. (1991): Az elmaradottság előnyeire alapozott jövőkép a Csereháton. Településfejlesztés, 3., 28-32.

G. Fekete É. (1994): Komplex térségfejlesztés és szociálpolitika. A falu, 4., 55-63.

G. Fekete É. (1995): Közösségi összefogáson alapuló térségfejlesztés. In: Kovács T. (szerk.): A mezőgazdaságtól a vidékfejlesztésig, III. Falukonferencia. MTA Regionális Kutatások Központja, Pécs, 391-398.

G. Fekete É. (1998): Bevezetés az alulról vezérelt (bottom-up) vidékfejlesztés elméletébe és módszertanába. Kereskedelmi és Gazdasági Főiskola, Szolnok

G. Fekete É. (1999a): Kistérségi fejlesztő szervezetek Magyarországon az új évezred küszöbén. Kutatási zárójelentés. MTA Regionális Kutatások Központja, Észak-magyarországi Osztály, Földművelési és Vidékfejlesztési Minisztérium, Miskolc

G. Fekete É. (1999b): Emberközpontú regionális fejlesztési stratégia követésének lehetősége BAZ megyében. In: Kocziszky Gy. (szerk.): Regionális fejlesztés a jövő szolgálatában. Miskolci Egyetem Regionális Gazdaságtani Tanszék, Miskolc, 95-106.

G. Fekete É. (2000a): A siker titkai a kistérségi fejlesztésekben. In: Kovács T. (szerk.): Integrált vidékfejlesztés. V. falukonferencia. MTA Regionális Kutatások Központja, Pécs, 54-62.

G. Fekete É. (2000b): Mit kell tudni egy térségmenedzsernek? Észak-Kelet Magyarország Gazdaság Kultúra Tudomány, 4-5., 60-65.

G. Fekete É., Velkey G. (2002): Tartós munkanélküliség és kezelése vidéki térségekben - kutatási zárótanulmány In: G. Fekete É. (szerk.): A tartós munkanélküliség kezelése vidéki térségekben. MTA Regionális Kutatások Központja, Vidékfejlesztési Műhely, Miskolc, Pécs, 9-60.

G. Fekete É. (2003): Nagy létszámú romaközösségekkel megvalósított szociális földprogrammodellek a Csereháton. In: Szoboszlai Zs. (szerk.): Cigányok a szociális földprogramban. Gondolat Kiadó, Budapest,143-163.

G. Fekete É. (2004): Az önkormányzatok felkészültsége az Európai Unió regionális politikájának fogadására. In: Szigeti E. (szerk.) Az önkormányzati közigazgatás az EU-csatlakozás tükrében. Magyar Közigazgatási Intézet, Budapest, 297-324.

G. Fekete É., Solymári G. (2004): A szociális gazdaság kiépítésének esélye és feltételei az Észak-Magyarországi Régióban. Észak-magyarországi Stratégiai Füzetek, 2., 32-78.

G. Fekete É. (2007): A szolidáris gazdaság elméleti és gyakorlati kérdései. In: Gubik A. (szerk.): VI. Nemzetközi konferencia a közgazdászképzés megkezdésének 20. évfordulója alkalmából. Miskolci Egyetem Gazdaságtudományi Kar, Miskolc, 79-89.

G. Fekete É. (2011): A szolidáris és szociális gazdaság elemei a magyarországi helyi gazdaságfejlesztésben. Észak-magyarországi Stratégiai Füzetek, 2., 38-56.

G. Fekete É., Lipták K. (2014): Közfoglalkoztatásból szociális szövetkezet? In: Lukovics M., Zuti B. (szerk.): A területi fejlődés dilemmái. Szegedi Tudományegyetem Gazdaságtudományi Kar, Szeged, 123-142.

G. Fekete É. (2015): A vidéki munkanélküliség tömegessé válásától az új foglalkoztatási modellekig. Herman Ottó Intézet, Miskolc

G. Fekete É. (2017): A társadalmi gazdaság posztszocialista sajátosságai Kelet-Közép-Európában. Közép-európai közlemények, 1., 59-74.

G. Fekete É. (2018): A társadalmi gazdaság posztszocialista sajátosságai Kelet-Közép-Európában. In: G. Fekete É., Nagy Z., Lipták K., Kiss J. (szerk.): Szociális és szolidáris gazdaság a poszt-szocialista perifériákon. Miskolci Egyetem Gazdaságtudományi Kar, Miskolc, 103-117.

G. Fekete É., Hubai L., Kiss J., Mihály M. (2018): Társadalmi vállalkozások Magyarországon. In: G. Fekete É., Nagy Z., Lipták K., Kiss J. (szerk.): Szociális és szolidáris gazdaság a poszt-szocialista perifériákon. Miskolci Egyetem Gazdaságtudományi Kar, Miskolc, 117-145. 
G. Fekete É., Nagy Z., Lipták K., Kiss J. (szerk.) (2018): Szociális és szolidáris gazdaság a poszt-szocialista perifériákon. Miskolci Egyetem Gazdaságtudományi Kar, Miskolc

Giddens, A. (1998): The Third Way: The Renewal of Social Democracy. Polity Press, Cambridge

Guerin, I. (2014): Solidarity Economy Revisited in the Light of Gender: a Tool for Social Change or Reproducing the Subordination of Women? In: Verschuur, C., Guerin, I., Guetat-Bernard, H. (eds.): Underdevelopment Gender. Palgrave MacMillen, London, 286-306.

Havas, A., Molnár, Gy. (2017): Evolution of Social Co-operatives in Hungary - Organic development distorted by state interventions. The role of the State in Economic Development. Thee 29th Annual EAEPE Conference, Budapest, 19-21. October 2017. https://www.researchgate.net/publication/ 320616110_The_Evolution_of_Social_Cooperatives_in_Hungary_Organic_development_distorte d_by_state_interventions (Letöltés: 2020.06.24.)

Hubai L. (2017): Beágyazott dilemma: a munkaerő-piaci integrációt segítő társadalmi vállalkozások összetett jellegének vizsgálata. Észak-magyarországi Stratégiai Füzetek, 1., 20-39.

Hubai L. (2016): Demokratikus szolidaritás: A társadalmi vállalkozások fogalmának és politikai dimenziójának vizsgálata. Esély Társadalom- és szociálpolitikai folyóirat, 3., 62-91.

Hubai L. (2019): Beágyazott dilemma - A munkaerőpiaci integrációt segitő társadalmi vállalkozások müködése Magyarországon. PhD Disszertáció, Kézirat

ILO (2019): Social and Solidarity Economy. https://www.ilo.org/empent/areas/WCMS_546299/ lang--en/index.htm https://www.ilo.org/global/about-the-ilo/how-the-ilo-works/ilodirector-general/statements-and-speeches/WCMS_677542/lang--en/index.htm (Letöltés: 2020.06.12.)

Kawano, E. (2013): Social Solidarity Economy: Toward Convergence across Continental Divides. News and Views. UNRISD conference "Potential and Limits of Social and Solidarity Economy". https:// www.unrisd.org/thinkpiece-kawano (Letöltés: 2020.06.19.)

Keller J., Bódis L. (2012): Települési önkormányzatok. In: Fazekas K., Scharle Á. (szerk.): Nyugdíj, segély, közmunka. A magyar foglalkoztatáspolitika két évtizede, 1990-2010. MTA KRTK Közgazdaságtudományi Intézet, Budapest Szakpolitikai Elemző Intézet, Budapest, 63-76.

Keller J., Rácz K., Váradi M. M. (2016): Közösségi gazdaságfejlesztés a vidéki Magyarországon. In: Kovács K. (szerk.): Földből élők Polarizáció a Magyar vidéken. Argumentum Kiadó, Budapest, 207-229.

Kiss J. (2018): A társadalmi vállalkozások megjelenése, intézményesülése és kapcsolódása a nonprofit szektorhoz Magyarországon. Doctoral dissertation. Eötvös Loránd Science University Faculty of Social Sciences, Doctoral School of Sociology, Programme of Social Policy, Budapest (kézirat).

Laville, J. L. (2010): Solidarity economy. In: Hart, K., Laville, J. L., Cattani, A. D. (eds.): The human economy. Polity Press, Cambridge, 225-235.

Laville, J.L. (2014): The social and solidarity economy: A theoretical and plural framework. In: Defourny, J., Hulgård, L., Pestoff, V. (eds.) Social enterprise and the third sector: Changing European landscape in a comparative perspective. Routledge, London, 102-114.

Laville, J. L. (2015): Social and solidarity economy in historical perspective. In: Utting, P. (eds.): Social and solidarity economy: Beyond the fringe. Zed Books, London, 41-56.

Laville, J. L. (2018): A szociális és szolidáris gazdaság történetének áttekintése. In: G. Fekete É., Nagy Z., Lipták K., Kiss J. (2018): Szociális és szolidáris gazdaság a poszt-szocialista perifériákon. Miskolci Egyetem Gazdaságtudományi Kar, Miskolc, 11-22.

Lipták K., Nagy Z., Dabasi-Halász Zs., Siposné Nándori E. (2019): Áttekintés a magyarországi szociális gazdaságról és gazdasági szervezeteiről. Szociálpolitikai Szemle, 1., 7-19.

McMurtry, J. J. (2018): Prometheus, trójai faló, vagy Frankenstein? A szociális és szolidáris gazdaság értékelése. In: G. Fekete É., Nagy Z., Lipták K., Kiss J. (2018): Szociális és szolidáris gazdaság a poszt-szocialista perifériákon. Miskolci Egyetem Gazdaságtudományi Kar, Miskolc, 63-74.

Mezei C. (2006). A helyi gazdaságfejlesztés fogalmi meghatározása. Tér és Társadalom, 4., 85-96. https://doi.org/10.17649/TET.20.4.1079

Mihály M. (2017): Mit értünk társadalmi vállalkozás alatt és miért kutatjuk? - Narratívák a nemzetközi szakirodalomból. Észak-magyarországi Stratégiai Füzetek, 1., 101-115. 
Mihály M. (2018): Poszt-szocialista átalakulás a vidéki terekben. A rurális gazdaság szerepe a rurális területek periferializálódásának visszafordításában. In: G. Fekete É., Nagy Z., Lipták K., Kiss J. (2018): Szociális és szolidáris gazdaság a poszt-szocialista perifériákon. Miskolci Egyetem Gazdaságtudományi Kar, Miskolc, 225-243.

Miller, E. (2007): Other Economies Are Possible! Building a Solidarity Economy. GEO Collective http:// www.geo.coop/node/35 (Letöltés: 2020. 06. 10.)

Miller, E. (2018): Szolidáris gazdaság. Kulcsfogalmak és témakörök. In: G. Fekete É., Nagy Z., Lipták K., Kiss J. (2018): Szociális és szolidáris gazdaság a poszt-szocialista perifériákon. Miskolci Egyetem Gazdaságtudományi Kar, Miskolc, 86-101.

Miniszterelnökség (2014): Magyarország Partnerségi Megállapodása a 2014-2020-as fejlesztési időszakra. https://www.palyazat.gov.hu/download.php?objectId=52032 (Letöltés: 2020.06 .23 .)

Monzón, J.L., Chaves, R. (2008): European Social Economy: Concept and Dimensions of the Third Sector. Annals of Public and Cooperative Economics, 3-4., 549-577. https://doi.org/10.1111/j.14678292.2008.00370.x

Moskvina, J., Tvaronavičienè, M. (2013): Social enterprises as a tool of social and economic policy, Lithuanian case. Entrepreneurship and Sustainability Issues, 1., 45-54. https://doi.org/10.9770/ jesi.2013.1.1(5)

Nándori E. S. (2020): A társadalmi vállalkozások munkaerőpiaci szerepe. Területi Statisztika, 2., 211223. DOI: $10.15196 /$ TS600205

Neamtan, N. (2002): Social and Solidarity Economy: Towards an 'Alternative' Globalisation. In: Preparation for the Symposium Citizenship and Globalization: Exploring Participation and Democracy in a Global Context e Carold Institute for the Advancement of Citizenship in Social Change. Langara College, Vancouver, June 14-16.2002. https://institute.coop/resources/social-and-solidarityeconomy-towards-'alternative'-globalisation (Letöltés: 2020.06.10.)

Nirello, L., Prouteau, L. (2018): The Frech Nonprofit sector. BRILL: Leiden, Boston

NKE (2001): Nonprofit Kutatócsoport Egyesület: A szociális gazdaság munkahely-teremtõ képessége és helyi szintû mobilizálásának, illetve legális keretek közé terelésének lehetõsége. In: Frey M. (szerk.): EU-konform foglalkoztatáspolitika. A hazai foglalkoztatáspolitika átalakítása a közösségi gyakorlatnak megfelelöen. OFA, Budapest, 367-385.

NGM - Nemzetgazdasági Minisztérium (2016): Felhivás társadalmi vállalkozások ösztönzése - kiemelt projekt GINOP-5.1.2. https://www.palyazat.gov.hu/ginop-512-trsadalmi-cl-vllalkozsok-sztnzse (Letöltés: 2020.07.01.)

OECD (1997a): The OECD Job Strategy: Making Work Pay: Taxation, Benefits, Employment and Unemployment. OECD Publishing, Paris

OECD (1997b): Beyond 2000: The New Social Policy Agenda. OECD Publishing, Paris

OECD (2003): The Nonprofit Sector in a Changing Economy. Local Economic and Employment Development (LEED). OECD Publishing, Paris https://doi.org/10.1787/9789264199545-en.

Petheő A. I. (2009): A vállalati társadalmi felelősségvállaláson túl: a szociális vállalkozás. Phd értekezés. Budapesti Corvinus Egyetem, Budapest

Podmenik, D., Adam, F., Milosevic, G. (2017): The challenges of social entrepreneurship in Slovenia. In: Social enterprise and sustainable societies. Louvain-la-Neuve, Belgium https://6emesconf.exordo.com/ files/papers/427/final_draftThe_Challenges_of_SE_in_Slovenia_EMES_Conference_Paper_2017_1 .pdf (Letöltés: 2020.06.25.)

Polányi, K. (1944): The Great Transformation. The political and economic origins of our time. Beacon Press, Boston

Repisky M., Tóth J. (2019): Mi motivál egy társadalmi vállalkozót? - Egy feltáró kvalitatív kutatás eredményei. Vezetéstudomány-Budapest Management Review, 3., 11-24. DOI: 10.14267/VEZTUD.2019.03.02

RIPESS (2015): Global Vision for a Social Solidarity Economy: Convergences and Differences in Concepts, Definitions and Frameworks. http://www.ripess.org/wp-content/uploads/2017/08/ RIPESS_Vision-Global_EN.pdf (Letöltés: 2020.06.24.)

SZITI (2006): Foglalkoztatási célú civil szervezetek helyzetének országos vizsgálata. SZITI Szociális Egyesület Budapest https://www.echosurvey.hu/_user/downloads/kutatasi_beszamolo/ t-NCA_zarotan0629.pdf (Letöltés: 2020.06 25.) 
Szolidáris Gazdaság Központ (2020): Gazdasági demokrácia és ökológiai fenntarthatóság: bemutatkozik a Szolidáris Gazdaság Központ. Mérce, 2020 május 10. https://merce.hu 2020/05/10/gazdasagidemokracia-es-okologiai-fenntarthatosag-bemutatkozik-a-szolidaris-gazdasag-kozpont/ (Letöltés: 2020.07.02.)

Teasdale, S. (2012): Negotating tensions: How do social enterprises in the homlessness field balance social and commercial considerations? Housing Studies, 4., 514-532. https:// doi.org/10.1080/02673037.2012.677015

Tortia, E. (2010): The impact of social enterprises on output, employment, and welfare. In: Becchetti, L., Borzaga, C. (eds.): The economics of social responsibility. Routledge, New York, 59-61.

Tóth L., Varga E., Varga P. (2011): A társadalmi vállalkozások helyzete Magyarországon. NESsT, Budapest

TSEP (1999): The Third System Employment and Local Development. Policy Research Institute, Metropolitan University, Leeds 